\title{
Review \\ Hormone replacement therapy and cognitive performance in postmenopausal women-a review by cognitive domain
}

\author{
Lee-Fay Low*, Kaarin J. Anstey \\ Centre for Mental Health Research, Australian National University, Building 63, Eggleston road, Canberra, ACT 0200, Australia
}

Received 8 December 2004; revised 12 May 2005; accepted 12 May 2005

\begin{abstract}
Laboratory, animal and neuroimaging evidences suggest that hormone replacement therapy (HRT) may be beneficial to human cognition. This systematic review includes 26 studies on the association between HRT and cognition and 17 studies on HRT and risk of dementia. It was hypothesised that HRT would have a positive association with cognitive speed and verbal memory and possibly visual memory but not with executive functioning, and would be associated with a decreased risk of dementia. Evidence for HRT's neuroenhancing and neuroprotective properties was also evaluated. There was significant statistical and clinical heterogeneity among studies precluding meta-analysis. Results showed no consistent relationship between HRT and performance in any cognitive domain. Cross-sectional studies tended to report more positive results than longitudinal studies and randomised-controlled trials, particularly in the areas of verbal memory and executive functioning. HRT was associated with decreased risk of dementia in observational studies, but with increased risk in one randomisedcontrolled trial. Cognitive improvement or maintenance are not secondary benefits of HRT.
\end{abstract}

(C) 2005 Elsevier Ltd. All rights reserved.

Keywords: HRT; Estrogen; Cognition; Dementia; Memory

\section{Contents}

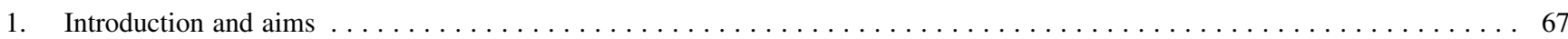

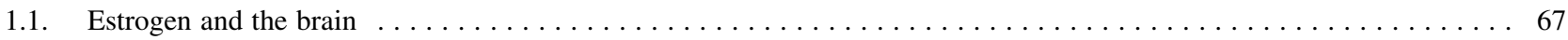

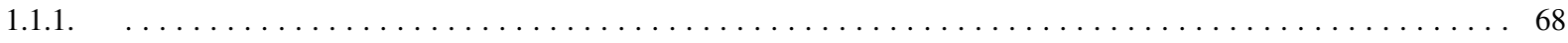

1.2. Indirect effects of estrogen on the brain via the cardiovascular system $\ldots \ldots \ldots \ldots \ldots \ldots$

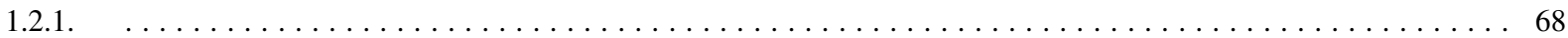

1.3. Methodological considerations of HRT and cognition studies $\ldots \ldots \ldots \ldots \ldots \ldots$

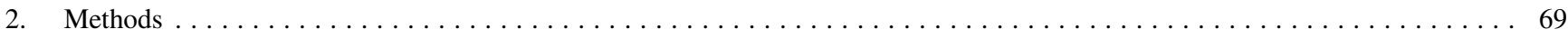

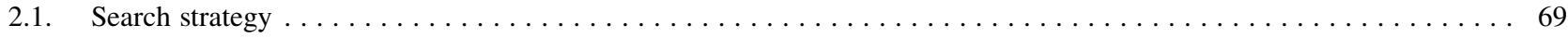

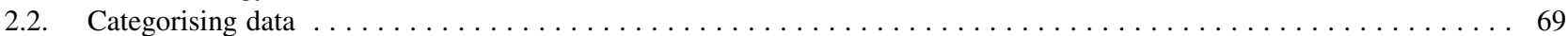

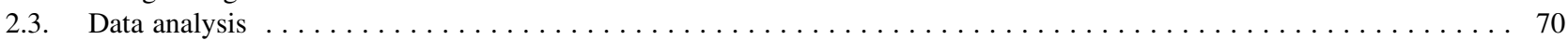

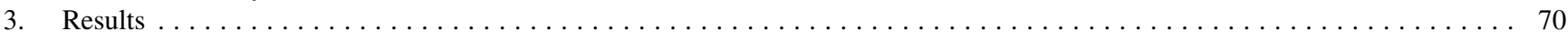

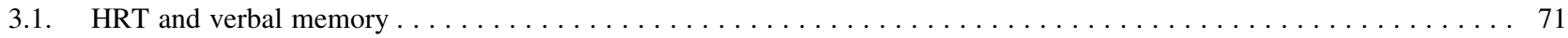

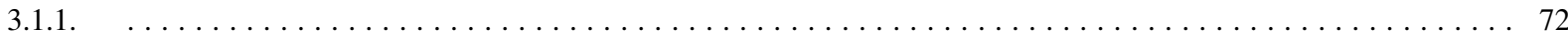

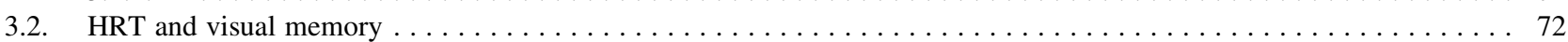

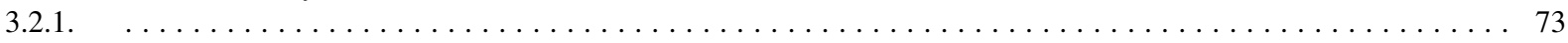

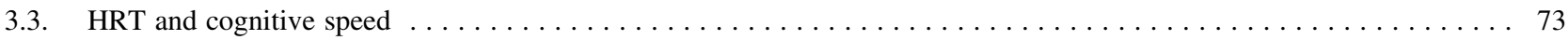

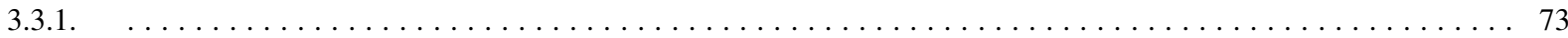

\footnotetext{
* Corresponding author. Tel.: +6126125 3132; fax: +61261250733.

E-mail address: lee-fay.low @anu.edu.au (L.-F. Low).
} 


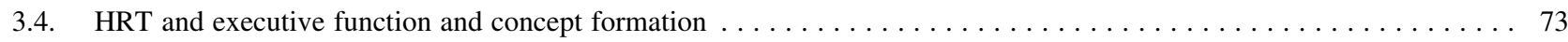

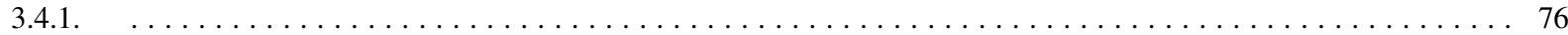

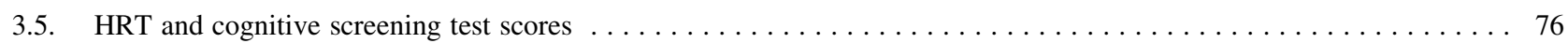

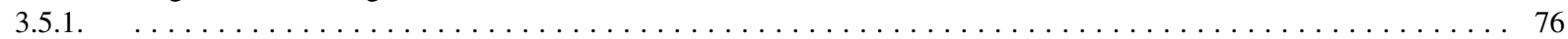

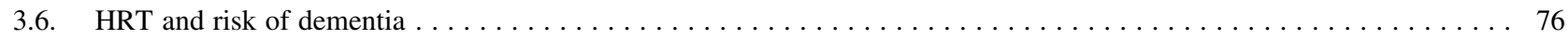

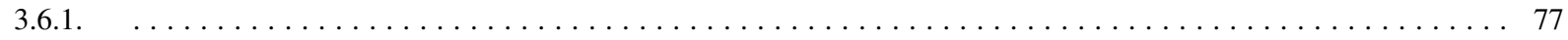

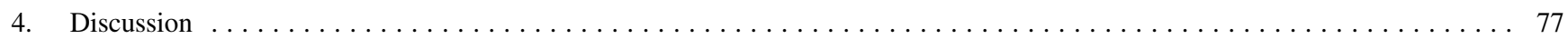

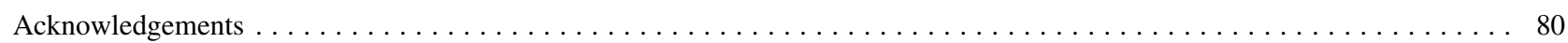

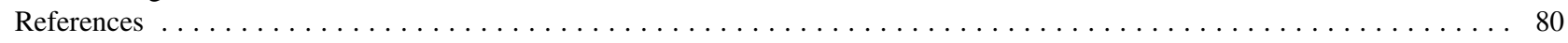

\section{Introduction and aims}

Hormone replacement therapy (HRT) consists of estrogen therapy alone or with the addition of progesterone, and was originally used to relieve symptoms of menopause such as hot flushes and genitourinary changes. Additional benefits were subsequently observed including reduced risk of osteoporosis, coronary heart disease and Alzheimer's disease (Fillit, 2002; Genazzani and Gambacciani, 1999; Lip et al., 1995).

The objective of this review is to systematically examine the evidence for a relationship between hormone replacement therapy and cognition. There have been several recent reviews in the area, including a Cochrane review of randomised-controlled trials (Hogervorst et al., 2004), a review of observational and experimental studies in postmenopausal women (Zec and Trivedi, 2002) and a meta-analysis of HRT and dementia risk (LeBlanc et al., 2001). This paper adds to this literature by asking more detailed questions about the HRT-cognition relationship. Specifically, this paper aims to review the evidence that HRT improves or maintains cognition in the domains of verbal memory, visual memory, speed, executive functioning and concept formation. Additionally, the evidence that HRT improves or maintains performance on cognitive screening instruments and reduces risk of dementia is systematically reviewed. Results are examined in relation to cognitive domains because if the effect of HRT is specific to one cognitive ability, pooling data across cognitive domains may dilute the observable effect of HRT on that specific ability. It is also likely that other variables, particularly those that affect exposure, such as duration of use, influence the observed associations between HRT and cognition. Further, this study will investigate whether age is associated with the effect of estrogen on cognition in human studies, as the animal literature suggests a differential effect of estrogen treatment with age (Adams et al., 2002; Lacreuse et al., 2002; Rapp et al., 2003a). Hence this paper aims to investigate whether age at assessment and duration of HRT have a moderating effect on the influence of HRT on cognition.

Gender differences have been observed on cognitive performance, with women generally performing better than men on verbal abilities and on tests of perceptual speed and accuracy, and men generally performing better than women in visuospatial tasks (Lezak et al., 2004). These differences suggest that estrogen may enhance verbal abilities. Human neuroimaging studies also report changes associated with HRT in the hippocampus (see below for details), an area associated with verbal and visual memory and learning. Hence it is hypothesised that estrogen will improve or maintain cognitive function in the domains of verbal memory and speed, and possibly on visual memory but not in the domain of executive function and concept formation.

A secondary objective of this review is to examine the evidence supporting estrogen's role as a neuroenhancer or a neuroprotector. If estrogen acts as a neuroenhancer, then it would be expected that at sufficient doses HRT would improve cognition, in one or more domains. This beneficial effect would be apparent whenever HRT was being taken, but not after HRT use was terminated. Whereas estrogen's neuroprotective effect would only be expected when nonHRT users are observed to be declining longitudinally while HRT users maintain their cognitive status. Hence HRT's neuroprotective effect may only be evident on cognitive testing in cohorts where cognitive aging is evident. HRT may only offer neuroprotection if estrogen levels are maintained through the menopausal and postmenopausal periods. If HRT does act as a neuroprotectant, it is plausible that both long-term current and past HRT use may have beneficial effects on cognition, and that HRT will be associated with better performance on cognitive screening instruments and with reduced risk of dementia.

\subsection{Estrogen and the brain}

HRT may impact on cognition through two pathways: by acting directly on brain systems and structure, or by acting indirectly on the brain through the cardiovascular system.

Laboratory and animal studies suggest that estrogen stimulates neurogenesis in the temporal lobes and prefrontal cortex (Lee and McEwen, 2001; Murphy et al., 1998; Murphy and Segal, 2000; Ormerod and Galea, 2001; Tanapat et al., 1999; Tang et al., 2004), and is involved in maintaining the function of the cholinergic system (Gibbs, 1998; Kompoliti et al., 2004; Kritzer and Kohama, 1999; Singh et al., 1994, 1995). Estrogen has also been shown in animal studies to protect against a variety of neurotoxic insults such as cell death induced by inhibition of mitocondrial function, suppression of glucose metabolism, alteration of nitric oxide production, induced stroke, 
administration of substances such as beta-amyloid peptide, excitatory amino acids and free radicals (Wise, 2003a,b). However, there are circumstances under which estrogen does not offer neuroprotection such as when cerebral injury is severe, and in animal models of epilepsy (Wise, 2003a). Laboratory and animal study results are not directly generalisable to the use of HRT in humans.

The impact of HRT on human brains has been examined using neuroimaging technology, although most studies to date have been limited by small sample size and crosssectional design. Observational studies have published evidence that HRT users have better brain structure as quantified by the area of white matter hyperintensities (Schmidt et al., 1996), anterior and posterior ventricular CSF (Cook et al., 2002), hippocampal volumes (Eberling et al., 2003), 5-HT2a receptor binding in the prefrontal region (Kugaya et al., 2003), and blood flow in the hippocampus, parahippocampal gyrus and temporal lobe (Maki and Resnick, 2000). But other studies (including one with over 2000 subjects) found no association between HRT and ventricular volume, total brain, grey and white matter volumes, or frontal, parietal, temporal and occipital volumes (Resnick et al., 1998), cortical atrophy, sulcal widening and white matter disease (Luoto et al., 2000). Lower levels of choline (a marker of inflammation) (Robertson et al., 2001) and less central atrophy (Luoto et al., 2000) have been found in women taking HRT compared with women not taking HRT.

\subsection{1}

Laboratory and animal studies support the theory that estrogen enhances brain structure and systems important in memory and has neuroprotective properties. Human neuroimaging studies have reported inconsistent results regarding the association of HRT with brain structure.

\subsection{Indirect effects of estrogen on the brain via the cardiovascular system}

It is possible that HRT may influence cognition and dementia risk indirectly via its effects on the cardiovascular system (Clinical Synthesis Panel on HRT, 1999; Gorelick et al., 1999). Clinically defined vascular disease, including heart failure, stroke, coronary heart disease, plaques in the carotid arteries, and peripheral arterial atherosclerotic disease, have been associated with poorer cognitive performance and risk of dementia (Breteler et al., 1994; de la Torre, 2004; Verhaegen et al., 2003). Cardiovascular risk factors such as cholesterol, diabetes, blood pressure and homocysteine have also been linked to cognitive function in old age (Coker and Shumaker, 2003; Lithell et al., 2003; Teunissen et al., 2003; Yaffe et al., 2002).

Randomised-controlled trials of HRT have shown that HRT lowers LDL cholesterol, raises HDL cholesterol (Espeland et al., 1998; Herrington et al., 2000;
Shlipak et al., 2003) and reduces the risk of diabetes (Kanaya et al., 2003; Margolis et al., 2004; Rossi et al., 2004). Some, but not all randomised trials have reported that estrogen replacement reduces blood pressure in subjects not treated with antihypertensives (Angerer et al., 2001b; The Writing Group for the PEPI Trial, 1995) and decreases homocysteine (Evio et al., 2000; Farag et al., 2003; Hak et al., 2001; Mijatovic et al., 1998; Os et al., 2002; van Baal et al., 1999; Ventura et al., 2001; Walsh et al., 2000).

None of the seven published randomised-controlled trials of HRT of the secondary prevention of coronary heart disease have reported a positive result (Angerer et al., 2001a; Clarke et al., 2002; Grady et al., 2002; Herrington et al., 2000; Hulley et al., 1998; Schulman et al., 2002; Viscoli et al., 2001; Waters et al., 2002). There have been two published randomised-controlled trials using HRT for the primary prevention of CHD (Hodis et al., 2001; The Women's Health Initiative Steering Committee, 2004; Writing Group for the Women's Health Initiative Investigators et al., 2002). The Estrogen in the Prevention of Atherosclerosis Trial (EPAT) found that the average rate of progression of subclinical atherosclerosis was lower in those taking HRT than placebo after 2 years in women who did not receive lipid-lowering medication (Hodis et al., 2001). The Women's Health Initiative Study reported that subjects in the estrogen and progestin arm had increased rates of coronary heart disease, stroke and blood clots compared to placebo after 5 years (Writing Group for the Women's Health Initiative Investigators et al., 2002) and women in the estrogen only arm had increased risk of stroke and no change in risk of coronary heart disease (The Women's Health Initiative Steering Committee, 2004). This increase in stroke and cardiovascular disease was accompanied by an increased risk of cognitive decline and dementia (Espeland et al., 2004; Rapp et al., 2003b; Shumaker et al., 2004, 2003).

\section{2 .1}

HRT has some beneficial effects on LDL and HDL cholesterol and diabetes risk. But with one exception, randomised-controlled trials of HRT consistently found no effect or a negative effect when treating or preventing coronary heart disease. This suggests that HRT may not have a positive effect on the cardiovascular system, and hence does not influence cognition through improvement of cardiovascular health.

\subsection{Methodological considerations of HRT and cognition studies}

There are limitations to both observational studies and randomised trials in the study of the association between HRT and cognition. In observational studies, 'healthy user' and socio-economic bias may confound the relationship between hormone use and cognition (Finley et al., 2001; Grodstein, 1996). Women who commence 
HRT are better educated, healthier and more self-aware of feelings, motives and symptoms before HRT use than women who do not commence HRT (Matthews et al., 1996). Women with more severe symptoms of menopause are more likely to be prescribed HRT (Bardel et al., 2002), and these symptoms of menopause may also have a negative influence on cognition. Estrogen may alleviate symptoms of depression associated with menopause (Campbell and Whitehead, 1977; Ditkoff et al., 1991), and this may confound cognitive test results, although the estrogen-mood association has not been firmly established (Stephens and Ross, 2002). Many observational studies are cross-sectional, making it impossible to infer causality. Detailed information on type, dose and duration are usually not obtained in larger observational studies and the accuracy of self-report data cannot be ascertained. Compliance with hormone replacement use is also not known. Cohort effects may influence results as the proportion of women using HRT use is increasing (Bakken et al., 1997; Lawrence et al., 1999; MacLennan et al., 2002; North and Sharples, 2001) as are the rates of risk factors for 'lifestyle-related' diseases (Galobardes et al., 2003; McMichael et al., 2004). Publication bias towards significant results, particularly in cross-sectional population studies, may create an overall positive bias.

Randomised-controlled trials provide a higher level of evidence on the effectiveness of a treatment than observational studies (National Health and Medical Research Council, 2001), nonetheless, such trials have their own limitations. Randomised-controlled trials allow better control for confounders, exact knowledge on dose, type and compliance, and can involve more detailed neuropsychological assessment. But such trials are expensive, so many include smaller samples. Randomised trials recruit volunteers who may not be representative of general populations. Many trials tend to be short (less than 1 year), therefore not allowing the examination of the long-term effect of hormone replacement therapy. Several of the larger trials of estrogen therapy have had the primary aim of treatment or prevention of coronary heart disease, and only administered short cognitive screening instruments designed to detect dementia and that are not sensitive to subclinical cognitive change. Other criticisms of randomised HRT and coronary heart disease trials are that their samples are dissimilar to the women who begin taking HRT for the amelioration of menopausal symptoms as they are selected to have heart disease, or had been postmenopausal for some time before commencing HRT (Grady et al., 2002; Naftolin et al., 2004). Trials tend to only use one type and mode of estrogen therapy, not informing on the effects of other hormone regimens. The large randomised-controlled trials have orally administered conjugated equine estrogen, and there have been arguments that other less tested forms of estrogen (such as 17 $\beta$-estradiol) may have beneficial effects on cognition (Asthana, 2004).

\section{Methods}

\subsection{Search strategy}

Articles examining the relationship between hormone replacement therapy and cognition were obtained by searching Medline and Psychinfo databases from 1966 to June 2004 using the keywords 'estrogen' or 'oestrogen' and 'cognition' or 'memory' or 'dementia' or 'Alzheimer\$'. Articles were included if they reported original data on the relationship between estrogen replacement and cognition or dementia, involved postmenopausal females, objectively measured cognition or a diagnosis of dementia, and were in English. Reference lists of articles obtained and other review papers were also searched for appropriate articles. Studies that had a sample size below 50 were excluded, as they were most likely to produce spurious results through biased subject selection.

Where insufficient data were available in the published article, a request was made for this data from the corresponding author by email. Efforts were made to obtain the most up-to-date email address and a reminder was sent after a month if no response was obtained. Data were grouped by cognitive domain and study design as there was variability between studies in terms of design (observational cross-sectional data, observational longitudinal data, randomised-controlled trials) and cognitive domains tested (verbal memory, visual memory, speed, executive performance and concept formation, and cognitive screening instruments). Other differences between studies such as sample characteristics (age, type and duration of HRT use, cardiovascular disease status) were also noted.

\subsection{Categorising data}

There were several ways of defining 'HRT users'. Some studies included only current HRT users, some included women who had ever used HRT and some also analysed data for past HRT users. Where HRT users were defined in several ways in one paper, data for current users were included here.

The types of neuropsychological tests grouped by cognitive domain are listed in Table 1. If a study reported more than one neuropsychological measure for a cognitive domain (e.g. list learning and paragraph recall), the mean effect size for that cognitive domain for that study was used so as to not to over-represent those studies that employed multiple tests. Verbal memory tests were those involving learning of lists of words, or digits, and the content of stories, with or without reminding of forgotten words. Visual memory tests were those involving memory for visual stimuli including, faces, figures and spatial locations. Speed tests were reaction time tasks, and timed tasks involving simple pattern matching or joining. Executive function and concept formation tests involved the manipulation of either visual or verbal information. 
Table 1

Neuropsychological tests grouped under each cognitive domain

\begin{tabular}{|c|c|c|c|c|}
\hline Verbal memory & Visual memory & Speed & $\begin{array}{l}\text { Executive function/ } \\
\text { concept formation }\end{array}$ & $\begin{array}{l}\text { Cognitive screening } \\
\text { instruments }\end{array}$ \\
\hline $\begin{array}{l}\text { Digit span forwards } \\
\text { and backwards } \\
\text { Paired verbal associates } \\
\text { Word list recall } \\
\text { Paragraph recall } \\
\text { Selective reminding test }\end{array}$ & $\begin{array}{l}\text { Spatial working memory } \\
\text { Memory for faces } \\
\text { Memory for figures } \\
\text { Corsi block-tapping }\end{array}$ & $\begin{array}{l}\text { Simple and complex reaction time } \\
\text { Trails A } \\
\text { Digit symbol substitution } \\
\text { Figure and letter cancellation }\end{array}$ & $\begin{array}{l}\text { Block design } \\
\text { Trails B } \\
\text { Wisconsin card sort } \\
\text { Card rotations } \\
\text { Similarities } \\
\text { Number letter } \\
\text { sequencing } \\
\text { Abstract reasoning } \\
\text { Mental rotation } \\
\text { Word generation by } \\
\text { letter and category }\end{array}$ & $\begin{array}{l}\text { MMSE } \\
\text { 3MSE } \\
\text { TICS } \\
\text { Cognitive abilities } \\
\text { screening instrument } \\
\text { Short Blessed score }\end{array}$ \\
\hline
\end{tabular}

Cognitive screening instruments were tests usually used for the detection of cognitive impairment. These tests are brief, and usually involved several simple tasks in multiple cognitive domains.

\subsection{Data analysis}

Data were analysed using STATA 7.0 software. Effect sizes were calculated for cognitive outcome measures and risk ratios were calculated when dementia was the outcome. Effect sizes were calculated as the standardised mean difference between groups, i.e. taking the difference between HRT and non-HRT groups, then dividing by the pooled standard deviation. Risk ratios were calculated by taking the proportion of subjects who developed dementia in the HRT group and dividing by the proportion who developed dementia in the non-HRT group. Effect size magnitude was described according to criterion set out by Cohen with $d=0.20,0.50$ and 0.80 representing small, medium and large effect sizes, respectively (Cohen, 1988).

Chi-squared tests for statistical heterogeneity of studies in each cognitive domain by study design were performed. Tests of statistical heterogeneity check whether the variation between study results is greater than would be expected with chance if there was a single treatment effect underlying all studies (Thompson, 1994). Since heterogeneity tests for meta-analysis are conservative, a $p$-value of 0.10 for significance was used (Petitti, 2001). If data in a group were statistically heterogeneous, sources of heterogeneity were explored through meta-regression and subgroup analysis. Clinical heterogeneity, the differences between studies in terms of subject selection and outcome measures were subjectively examined.

Meta-regression examines the association between effect size and one or more characteristics of the studies, similar to the way linear regression examines the relationship between a dependent variable and one or more independent variables (Thompson and Higgins, 2002). Meta-regression was used to test the hypothesis that sample age at assessment and duration of HRT affected the relationship between HRT and cognition. Where appropriate, heterogeneity was also explored using sub group analysis, e.g. only including studies using similar neuropsychological tests.

Publication bias was assessed using funnel plots in which study sample sizes ( $y$-axis) were plotted against the effect sizes ( $x$-axis). In the absence of bias, the graph will resemble an upside down funnel with the smaller studies scattered across the bottom of the graph (Deeks et al., 2002; Egger et al., 1997). Additionally, the Egger regression asymmetry test was performed (Egger et al., 1997). The Egger test regresses standardised effect sizes against their precision ( $1 /$ standard error) and tests whether the intercept deviates significantly from zero.

Data are presented in forest plots, which graphically represent the mean, 95\% confidence interval and size of each study. An a priori decision was made that if data were heterogenous, meta-analysis would not be performed. If clinical and statistical heterogeneity are present, the assumption that a single common 'fixed' effect underlies all studies is violated and fixed-effects meta-analysis should not be performed (Poole and Greenland, 1999). Random effects meta-analysis does not require heterogeneity, but assumes that the effects estimated by the studies follow some distribution, usually a normal distribution. Random effects analyses are more unpredictable than fixed effect models and do not always produce more conservative results (Deeks et al., 2002; Poole and Greenland, 1999). The lead author performed all literature searching and data analysis.

\section{Results}

In total one hundred and five full-text articles were obtained. Thirty-two articles did not meet the inclusion criteria of presenting original data, including postmenopausal women, or objectively measuring cognition or dementia status. Three cross-sectional studies (Keenan et al., 2001; Miller et al., 2002; Resnick et al., 1998), three longitudinal studies (Hogervorst et al., 1999; Maki and Resnick, 2000; Verghese et al., 2000), and nine randomised trials were excluded because of small sample sizes (Caldwell, 1954; 
Ditkoff et al., 1991; Duka et al., 2000; Hackman and Galbraith, 1976; Janowsky et al., 2000; Phillips and Sherwin, 1992; Sherwin, 1988; Vanhulle and Demol, 1976; Wolf et al., 1999). There were four articles each published on the cognitive and dementia outcomes for one study, the Women's Health Initiative (Espeland et al., 2004; Rapp et al., 2003b; Shumaker et al., 2004, 2003).

The final sample for this review consisted of 17 crosssectional (Carlson and Sherwin, 1998; Carlson et al., 2001; Duff and Hampson, 2000; Galen Buckwalter et al., 2004; Grodstein et al., 2000; Jacobs et al., 1998; Kimura, 1995; Luoto et al., 2000; Maki et al., 2001; Matthews et al., 1999; Resnick et al., 1997; Robinson et al., 1994; Schmidt et al., 1996; Steffens et al., 1999; Szklo et al., 1996; Whitmer et al., 2003), five longitudinal observational (Carlson et al., 2001; de Moraes et al., 2001; Jacobs et al., 1998; Kang et al., 2004; Matthews et al., 1999; Rauramo et al., 1975; Resnick et al., 1997; Rice et al., 2000) and four randomisedcontrolled trials (Binder et al., 2001; Goebel et al., 1995; Grady et al., 2002; Rapp et al., 2003b; Shaywitz et al., 2003; Shumaker et al., 2004, 2003) published on the relationship between HRT and cognition in cognitively intact postmenopausal women with data from which effect sizes could be calculated. Studies for which there were insufficient data to calculate effect sizes are described separately for each cognitive domain.

Descriptive data for these studies are presented in Tables 2-4 listed by sample age. Sample sizes for crosssectional studies ranged from 54 to 9651 and in total included 23,649 subjects. The mean age of subjects was 68.9 years (range 55.6-80 years). Ten of the studies recruited participants from population or organisational samples; six of the smaller studies recruited volunteers. The percentage of HRT users in the different studies ranged from 11 to $65 \%$. Where data on HRT type and administration were available, most women were taking oral conjugated equine estrogens. There was also clinical heterogeneity in terms of race, duration of HRT use and percentage also using progesterone, though these data were not available for all studies.

Sample sizes for longitudinal studies ranged from 88 to 13,807 women and included 21,933 women in total. The mean age of women in longitudinal studies was 71.5 (range 56.6-74.7 years). One study recruited the members of a nurses' organisation (Kang et al., 2004), and all others recruited from population samples. Similar to crosssectional studies, there were differences in race, proportion of HRT users, and progesterone users, and duration of use.

Sample sizes for randomised trials ranged from 52 to 4481 subjects and included 8603 women in total. Their mean age was 72.6 (range 51.2-81.0). All women were volunteers, one study exclusively recruited women with coronary disease (Grady et al., 2002) and another recruited women without clinically established coronary disease (Espeland et al., 2004; Rapp et al., 2003b). Coronary disease status was not specified in the other studies.
Eighteen studies were identified that published data on the relationship between HRT use and risk of dementia (1986; 1998; 2003; 1994; 1990; 2004; 1990; 1994; 1984; 1997; 2002; 1995; 1996b; 2001; 1999; 1996; 1999; Zandi et al., 2002). Characteristics of these studies are presented in Table 5. A total of 18,980 women were studied (sample size ranged from 84 to 7428 ) with an overall mean age of 73.5 years (mean age ranged from 58 to 87 years). The percentage of cases differed by design, with samples followed longitudinally having lower proportions of dementia cases than case-controlled studies. Nine studies defined HRT users as 'ever' users, and the other nine defined HRT users as 'current' users.

\subsection{HRT and verbal memory}

Twenty-two studies reporting results relating to verbal memory and HRT were identified. There was insufficient data to calculate effect sizes for five studies. Of these one reported a positive relationship (Kimura, 1995) and the others reported no relationship between HRT and verbal memory (Barrett-Connor and Kritz-Silverstein, 1993; Lokkegaard et al., 2002; Polo-Kantola et al., 1998; Rauramo et al., 1975). Hence data from eleven cross-sectional, three longitudinal and three randomised trials were examined which reported results of 50 tests of verbal memory. Test results were averaged for each study. Tests of statistical heterogeneity were significant for cross-sectional $\left(\chi^{2}=961.52, \mathrm{df}=11, p=0.000\right)$, longitudinal $\left(\chi^{2}=38.96\right.$, $\mathrm{df}=2, p=0.000)$ and randomised $\left(\chi^{2}=8.22, \mathrm{df}=2\right.$, $p=0.016$ ) trials.

Meta-regression revealed that neither age (coefficient $=-0.0005, p=0.972$ ) nor duration (coefficient $=$ $0.0026, p=0.890$ ) had a significant effect on standardised mean difference between groups. On visual inspection, the funnel plot appeared asymmetrical but Egger's test of funnel plot asymmetry was non-significant $(p=0.683)$.

The standardised mean difference between HRT and control groups on verbal memory for cross-sectional, longitudinal and randomised trials are shown in Fig. 1. The effect sizes ranged from small to large, but most are in the small range. Of cross-sectional studies, two found a negative relationship, two found no relationship and seven reported a positive relationship. Of longitudinal studies, one large trial reported a negative relationship, one reported no relationship and one reported a positive effect of HRT on cognition. Of the three randomised trials, two found no relationship and one reported a positive association.

To investigate whether this heterogeneity was due to differences in the tests of verbal memory, analyses were performed for results pertaining to specific tests in the cross-sectional studies where there were a sufficient number of studies to permit such sub-analysis. These included verbal list and story learning data (eight studies), digits forwards (five studies) and digits backwards (five studies). There was still significant 
Table 2

Cross-sectional observational studies

\begin{tabular}{|c|c|c|c|c|c|c|c|c|c|}
\hline Lead author & Study name & $\begin{array}{l}\text { Total sample } \\
\text { size }\end{array}$ & $\begin{array}{l}\text { Mean age } \\
( \pm S D)\end{array}$ & Race & $\begin{array}{l}\text { Sample } \\
\text { source }\end{array}$ & $\begin{array}{l}\text { HRT } \\
\text { groups }\end{array}$ & $\begin{array}{l}\text { Users } \\
(\%)\end{array}$ & $\begin{array}{l}\text { Mean dur- } \\
\text { ation (years) }\end{array}$ & $\begin{array}{l}\text { Progesterone } \\
\text { use }(\%)\end{array}$ \\
\hline Kimura (1995) & & 54 & - & - & Volunteers & Current & 39 & - & 24 \\
\hline Duff (2000) & & 96 & $55.6 \pm 5$ & - & Volunteers & Current & 40 & 5.8 & - \\
\hline Tivis (2003) & & 214 & 56 & - & Volunteers & Current & 65 & - & 52 \\
\hline Szklo (1996) & ARIC & 6100 & $58 \pm 0.1$ & $\begin{array}{l}74.5 \% \\
\text { Caucasian }\end{array}$ & Population & Current & 23 & - & - \\
\hline Schmidt (1996) & $\begin{array}{l}\text { Australian } \\
\text { Stroke } \\
\text { Prevention } \\
\text { Study }\end{array}$ & 210 & $60 \pm 6$ & Caucasian & Population & Current & 33 & $4.4 \pm 5$ & 24 \\
\hline Kampen (1994) & & 71 & $64.3 \pm 5$ & Caucasian & Volunteers & Current & 64 & - & 57 \\
\hline Resnick (1997) & & 288 & $65 \pm 10$ & Caucasian & Population & Ever & 40 & $\begin{array}{l}55 \% \\
\text { between } 1 \\
\text { and } 5\end{array}$ & - \\
\hline Maki (2001) & & 184 & $67 \pm 10$ & Caucasian & $\begin{array}{l}\text { Population } \\
\& \text { Organis- } \\
\text { ation }\end{array}$ & Current & 56 & Median 1-4 & 42 \\
\hline Robinson (1994) & & 144 & $67.2 \pm 6.5$ & - & Volunteers & Current & 50 & $13.4 \pm 7.5$ & 45 \\
\hline Whitmer (2003) & SALSA & 1041 & 70.3 & Latino & Population & Current & 21 & - & - \\
\hline Matthews (1999) & $\begin{array}{l}\text { Epidemio- } \\
\text { logy of } \\
\text { Hearing } \\
\text { Loss Study }\end{array}$ & 9651 & $71.7 \pm 5.3$ & Caucasian & Population & Current & 14 & $14.3 \pm 9.9$ & 21 \\
\hline Carlson (1998) & & 55 & $72.1 \pm 5$ & - & Volunteers & Current & 25 & 19.1 & 21 \\
\hline Grodstein (2000) & $\begin{array}{l}\text { Nurses } \\
\text { Health study }\end{array}$ & 2138 & 74 & Mixed & Organisation & Current & 33 & 12.8 & 28 \\
\hline Jacobs (1998) & & 727 & $74.2 \pm 6.9$ & Mixed & Population & Ever & 11 & $4.6 \pm 8.6$ & - \\
\hline Luoto (2000) & $\begin{array}{l}\text { Cardiovas- } \\
\text { cular Health } \\
\text { Study }\end{array}$ & 2133 & 74.8 & Mixed & Population & Current & 15 & - & 14 \\
\hline Steffens (1999) & $\begin{array}{l}\text { Cache } \\
\text { County } \\
\text { Study }\end{array}$ & 2338 & $75.1 \pm 6.8$ & Caucasian & Population & Current & 28 & - & - \\
\hline $\begin{array}{l}\text { Galen } \\
\text { Buckwalter (2004) }\end{array}$ & $\begin{array}{l}\text { Women's } \\
\text { Memory } \\
\text { Study }\end{array}$ & 105 & $77.8 \pm 2.1$ & $\begin{array}{l}98 \% \\
\text { Caucasian }\end{array}$ & Organisation & Current & 55 & $22.7 \pm 10.9$ & 24 \\
\hline
\end{tabular}

heterogeneity within these verbal memory subsets $\left(\chi^{2}=209.82, \quad \mathrm{df}=7, \quad p=0.000 ; \quad \chi^{2}=104.69, \quad \mathrm{df}=4\right.$, $p=0.000 ; \chi^{2}=104.69, \quad \mathrm{df}=4, p=0.000$, respectively). Using verbal list and story learning tests, seven studies reported no association and one study reported a positive association (data not shown). Using either digits forwards tests or digits backwards tests, two studies reported no association, and three reported positive associations between HRT and performance (data not shown).

\subsection{1}

There is some evidence for a positive association between HRT and verbal memory in cross-sectional data, though not in longitudinal or randomised-controlled trials. Clinical and statistical heterogeneity complicate interpretation.

\subsection{HRT and visual memory}

Ten of the studies reviewed reported results on the relationship between HRT use and visual memory. Of these, there was insufficient data to calculate effect sizes for four studies (Barrett-Connor and Kritz-Silverstein, 1993; Kampen and Sherwin, 1994; Lokkegaard et al., 2002; Polo-Kantola et al., 1998). These four reported no significant association between HRT use and visual memory. Data were analysed for five cross-sectional and one randomised-controlled trial that reported the results of 15 tests of visual memory. There was significant heterogeneity among cross-sectional trials $\left(\chi^{2}=204.4, \mathrm{df}=4\right.$, $p=0.000$ ). Neither age nor duration had a significant effect on standardised mean difference on meta-regression (coefficient $=0.0627, p=0.752 ;$ coefficient $=-0.670$, $p=0.765$, respectively). On visual inspection, the funnel plot appeared asymmetrical, but Egger's test of asymmetry was non-significant $(p=0.457)$.

The standardised mean difference between HRT and control groups on visual memory for cross-sectional, longitudinal and randomised trials are shown in Fig. 2. Two cross-sectional studies reported significant negative associations, one reported no association and two studies 
Table 3

Longitudinal observational studies

\begin{tabular}{|c|c|c|c|c|c|c|c|c|c|c|}
\hline $\begin{array}{l}\text { Lead } \\
\text { author }\end{array}$ & $\begin{array}{l}\text { Study } \\
\text { name }\end{array}$ & $\begin{array}{l}\text { Total } \\
\text { sample size }\end{array}$ & Mean age & Race & $\begin{array}{l}\text { Sample } \\
\text { source }\end{array}$ & HRT group & $\begin{array}{l}\text { No. of } \\
\text { users }(\%)\end{array}$ & $\begin{array}{l}\text { Mean } \\
\text { duration } \\
\text { (years) }\end{array}$ & $\begin{array}{l}\text { Progester- } \\
\text { one use } \\
(\%)\end{array}$ & $\begin{array}{l}\text { Follow-up } \\
\text { (years) }\end{array}$ \\
\hline $\begin{array}{l}\text { de Moraes } \\
(2001)\end{array}$ & ARIC & 2859 & $56.6 \pm 5.5$ & $\begin{array}{l}78.6 \% \\
\text { Caucasian }\end{array}$ & Population & Current & 32 & - & - & 6 \\
\hline $\begin{array}{l}\text { Rice } \\
(2000)\end{array}$ & $\begin{array}{l}\text { Kame } \\
\text { project }\end{array}$ & 895 & $71.4 \pm 5.4$ & Asian & Population & Current & 16 & $15 \pm 11.7$ & 32 & 2 \\
\hline $\begin{array}{l}\text { Yaffe } \\
(2000)\end{array}$ & $\begin{array}{l}\text { Cardiovas- } \\
\text { cular } \\
\text { Health } \\
\text { Study }\end{array}$ & 2380 & 72.3 & Mixed & Population & Current & 11 & - & - & \\
\hline $\begin{array}{l}\text { Kang } \\
(2004)\end{array}$ & $\begin{array}{l}\text { Nurses } \\
\text { Health } \\
\text { Study }\end{array}$ & 13,807 & $74.0 \pm 2.2$ & - & $\begin{array}{l}\text { Organis- } \\
\text { ation }\end{array}$ & Current & 36 & - & 28 & 2 \\
\hline $\begin{array}{l}\text { Carlson } \\
\text { (2001) }\end{array}$ & $\begin{array}{l}\text { Cache } \\
\text { County } \\
\text { Study }\end{array}$ & 1992 & $74.7 \pm 6$ & Caucasian & Population & Current & 38 & - & - & 3 \\
\hline
\end{tabular}

reported positive associations. The randomised-controlled trial found no effect of HRT on visual memory. Effect sizes ranged from small to large. It is notable that the study with the largest effect size of 2.27 (95\% CI 1.97-2.57) was the only one in this domain to categorise HRT use as 'ever' use.

\subsection{1}

There was no consistent association between HRT use and visual memory.

\subsection{HRT and cognitive speed}

Eight studies contained results relating to HRT and cognitive speed and all included enough data to calculate effect sizes. Five studies were cross-sectional, one was longitudinal, and two were randomised-controlled trials. There was significant heterogeneity among cross-sectional trials $\left(\chi^{2}=3077.90, \mathrm{df}=4, p=0.000\right)$ but the heterogeneity statistic between the two randomisedcontrolled trials was non-significant $\left(\chi^{2}=0.39, \mathrm{df}=1\right.$, $p=0.531$ ). When a meta-regression was performed, neither age nor duration were predictors of standardised mean difference (coefficient $=0.0021, p=0.877$, coefficient $=0.0111, p=0.427$, respectively). Publication bias was not detected using Egger's test of funnel plot asymmetry $(p=0.860)$.

The standardised mean differences for studies of HRT and speed are displayed in Fig. 3. Three cross-sectional studies reported no significant association between HRT and speed, and two cross-sectional studies both with large effect sizes reported a positive association, one longitudinal study reported no association. The two randomised trials found no association, with an overall non-significant effect between those two randomised trials.

\subsection{1}

HRT does not have a consistent association with speed of performance.

\subsection{HRT and executive function and concept formation}

Twenty-two studies were identified that published evidence relating HRT and executive function and concept formation. There were insufficient data to calculate effect

Table 4

Randomised trials

\begin{tabular}{|c|c|c|c|c|c|c|c|c|}
\hline Lead author & Study name & $\begin{array}{l}\text { Sample size } \\
\text { (HRT, controls) }\end{array}$ & Mean age & Race & $\begin{array}{l}\text { Duration } \\
\text { (months) }\end{array}$ & ERT mode & ERT type & $\begin{array}{l}\text { Progesterone } \\
\text { use }(\%)\end{array}$ \\
\hline $\begin{array}{l}\text { Shaywitz } \\
(2003)\end{array}$ & & 31,29 & $51.2 \pm 5$ & Caucasian & 0.75 & Oral & $\begin{array}{l}\text { Conjugated } \\
\text { equine estrogen }\end{array}$ & 0 \\
\hline Grady (2002) & HERS & 517,546 & $71 \pm 6$ & $\begin{array}{l}\text { Most } \\
\text { Caucasian }\end{array}$ & 48 & Oral & $\begin{array}{l}\text { Conjugated } \\
\text { equine estrogen }\end{array}$ & 100 \\
\hline \multirow[t]{2}{*}{$\begin{array}{l}\text { Rapp } \\
(2003 b), \\
\text { Espel (2004) }\end{array}$} & $\begin{array}{l}\text { WHI-estro- } \\
\text { gen and } \\
\text { progesterone } \\
\text { arm }\end{array}$ & 2145,2336 & $73 \pm 7.1$ & $\begin{array}{l}90 \% \\
\text { Caucasian }\end{array}$ & 54 & Oral & $\begin{array}{l}\text { Conjugated } \\
\text { equine estrogen }\end{array}$ & 100 \\
\hline & $\begin{array}{l}\text { WHI-estro- } \\
\text { gen only arm }\end{array}$ & 1464,1483 & Range $65-79$ & $\begin{array}{l}\text { Most } \\
\text { Caucasian }\end{array}$ & 63 & Oral & $\begin{array}{l}\text { Conjugated } \\
\text { equine estrogen }\end{array}$ & 0 \\
\hline $\begin{array}{l}\text { Binder } \\
(2001)\end{array}$ & & 34,18 & $81 \pm 3.5$ & $\begin{array}{l}85 \% \\
\text { Caucasian }\end{array}$ & 9 & Oral & $\begin{array}{l}\text { Conjugated } \\
\text { equine estrogen }\end{array}$ & 58 \\
\hline
\end{tabular}


Table 5

HRT and risk of dementia

\begin{tabular}{|c|c|c|c|c|c|c|c|c|c|c|}
\hline Lead author & Study name & $\begin{array}{l}\text { Total } \\
\text { sample }\end{array}$ & Mean age & Race & Sample source & Groups & $\begin{array}{l}\text { \# Users } \\
(\%)\end{array}$ & $\begin{array}{l}\text { Mean } \\
\text { dur- } \\
\text { ation } \\
\text { (years) }\end{array}$ & $\begin{array}{l}\% \text { Demen- } \\
\text { tia cases }\end{array}$ & $\begin{array}{l}\text { Follow- } \\
\text { up } \\
\text { (years) }\end{array}$ \\
\hline Amaducci (1986) & & 220 & - & $\begin{array}{l}\text { Mediterra- } \\
\text { nean }\end{array}$ & $\begin{array}{l}\text { Outpatients } \\
\text { (case-controlled) }\end{array}$ & Ever & 11 & - & 50 & - \\
\hline Heyman (1984) & & 84 & - & - & $\begin{array}{l}\text { Volunteers } \\
\text { (case-controlled) }\end{array}$ & Current & 10 & - & 33 & - \\
\hline Slooter (1999) & & 218 & $58 \pm 6$ & Caucasian & $\begin{array}{l}\text { Population } \\
\text { (case-controlled) }\end{array}$ & Current & 16 & - & 48 & - \\
\hline Kawas (1997) & $\begin{array}{l}\text { Baltimore } \\
\text { Longitudi- } \\
\text { nal Study } \\
\text { of Aging }\end{array}$ & 514 & 61.5 & $\begin{array}{l}92 \% \\
\text { Caucasian }\end{array}$ & Population & Ever & 45 & - & 7 & 16 \\
\hline Graves (1990) & & 260 & 63 & Caucasian & $\begin{array}{l}\text { Outpatients } \\
\text { (case-controlled) }\end{array}$ & Current & 17 & - & 50 & - \\
\hline Seshadri (2001) & $\begin{array}{l}\text { UK GP } \\
\text { research } \\
\text { database }\end{array}$ & 280 & 65.5 & Caucasian & $\begin{array}{l}\text { Population } \\
\text { (case-controlled) }\end{array}$ & Current & 24 & All $\geq 1$ & 21 & - \\
\hline $\begin{array}{l}\text { Shumaker } \\
(2004,2003)\end{array}$ & WHI & 7428 & $\begin{array}{l}\text { Range } \\
65-79\end{array}$ & $\begin{array}{l}\text { Most } \\
\text { Caucasian }\end{array}$ & $\begin{array}{l}\text { Volunteers } \\
\text { (RCT) }\end{array}$ & Current & 49 & 4.8 & 2.1 & 5 \\
\hline $\begin{array}{l}\text { Mortel and } \\
\text { Meyer (1995) }\end{array}$ & & 306 & $73.2 \pm 8$ & - & $\begin{array}{l}\text { Volunteers } \\
\text { (case-controlled) }\end{array}$ & Current & 15 & - & 51.6 & - \\
\hline Lindsay (2002) & $\begin{array}{l}\text { Canadian } \\
\text { Study of } \\
\text { Health and } \\
\text { Aging }\end{array}$ & 2079 & 73.3 & Caucasian & Population & Ever & 6 & - & 5 & 5 \\
\hline Baldereschi 1998 & $\begin{array}{l}\text { Italian } \\
\text { Longitudi- } \\
\text { nal Study } \\
\text { on Aging }\end{array}$ & 2046 & $74 \pm 6$ & $\begin{array}{l}\text { Mediterra- } \\
\text { nean }\end{array}$ & Population & Ever & 12 & - & 5 & - \\
\hline $\begin{array}{l}\text { Tang et al., } \\
\text { (1996) }\end{array}$ & $\begin{array}{l}\text { Northern } \\
\text { Manhattan }\end{array}$ & 1145 & $74.2 \pm 7.0$ & Mixed & Population & Ever & 13 & 6.8 & 15 & $1-5$ \\
\hline Zandi (2002) & $\begin{array}{l}\text { Cache } \\
\text { County } \\
\text { Study }\end{array}$ & 1889 & 74.5 & Caucasian & Population & Ever & 56 & 11.6 & 6.5 & 3 \\
\hline Barnes (2003) & $\begin{array}{l}\text { Religious } \\
\text { Order } \\
\text { Study }\end{array}$ & 577 & $76.1 \pm 7.0$ & $\begin{array}{l}\text { Most } \\
\text { Caucasian }\end{array}$ & Organisation & Ever & 36 & 9.2 & 16 & 5.8 \\
\hline $\begin{array}{l}\text { Henderson } \\
(1994)\end{array}$ & & 235 & $76 \pm 9$ & - & $\begin{array}{l}\text { Volunteers } \\
\text { (case-controlled) }\end{array}$ & Current & 12 & - & 60.9 & - \\
\hline Brenner (1994) & & 227 & $77 \pm 7$ & $\begin{array}{l}95 \% \\
\text { Caucasian }\end{array}$ & $\begin{array}{l}\text { Population } \\
\text { (case-controlled) }\end{array}$ & Current & 23 & 7.9 & 47 & - \\
\hline Broe (1990) & $\begin{array}{l}\text { Sydney } \\
\text { Older Per- } \\
\text { sons Study }\end{array}$ & 340 & $78.1 \pm 7$ & Caucasian & $\begin{array}{l}\text { General practice } \\
\text { (case-controlled) }\end{array}$ & Current & 9 & - & 50 & - \\
\hline Waring (1999) & $\begin{array}{l}\text { Rochester } \\
\text { Epidemiol- } \\
\text { ogy project }\end{array}$ & 444 & 82 & Caucasian & $\begin{array}{l}\text { Population } \\
\text { (case-controlled) }\end{array}$ & Ever & 18 & $\begin{array}{l}41 \% \\
\geq 0.5\end{array}$ & 50 & - \\
\hline $\begin{array}{l}\text { Paganini- } \\
\text { Hill and Hender- } \\
\text { son }(1996 b)\end{array}$ & $\begin{array}{l}\text { Leisure } \\
\text { World } \\
\text { Cohort }\end{array}$ & 688 & $87 \pm 6$ & Caucasian & $\begin{array}{l}\text { Population } \\
\text { (case-controlled) }\end{array}$ & Ever & 44 & - & 20 & $1-11$ \\
\hline
\end{tabular}

sizes in two studies that reported a positive association (Lokkegaard et al., 2002; Paganini-Hill and Henderson, 1996a), and in four studies that reported no association (Barrett-Connor and Kritz-Silverstein, 1993; Kampen and Sherwin, 1994; Polo-Kantola et al., 1998; Rauramo et al., 1975). Ten cross-sectional, three longitudinal and three randomised trials were examined and statistical heterogeneity was detected among cross-sectional trials $\left(\chi^{2}=868.57\right.$, $\mathrm{df}=9, p=0.000)$, longitudinal studies $\left(\chi^{2}=3099.18, \mathrm{df}=2\right.$, $p=0.000)$, and randomised-controlled trials $\left(\chi^{2}=8.42\right.$, $\mathrm{df}=2, p=0.015)$. To investigate whether heterogeneity was due to differences in the tests of executive functioning, analyses were performed for verbal fluency tests only. This did not improve heterogeneity among the five crosssectional, and three longitudinal studies that included verbal fluency tasks $\left(\chi^{2}=839.45, \mathrm{df}=4, p=0.000 ; \chi^{2}=3759.61\right.$, 


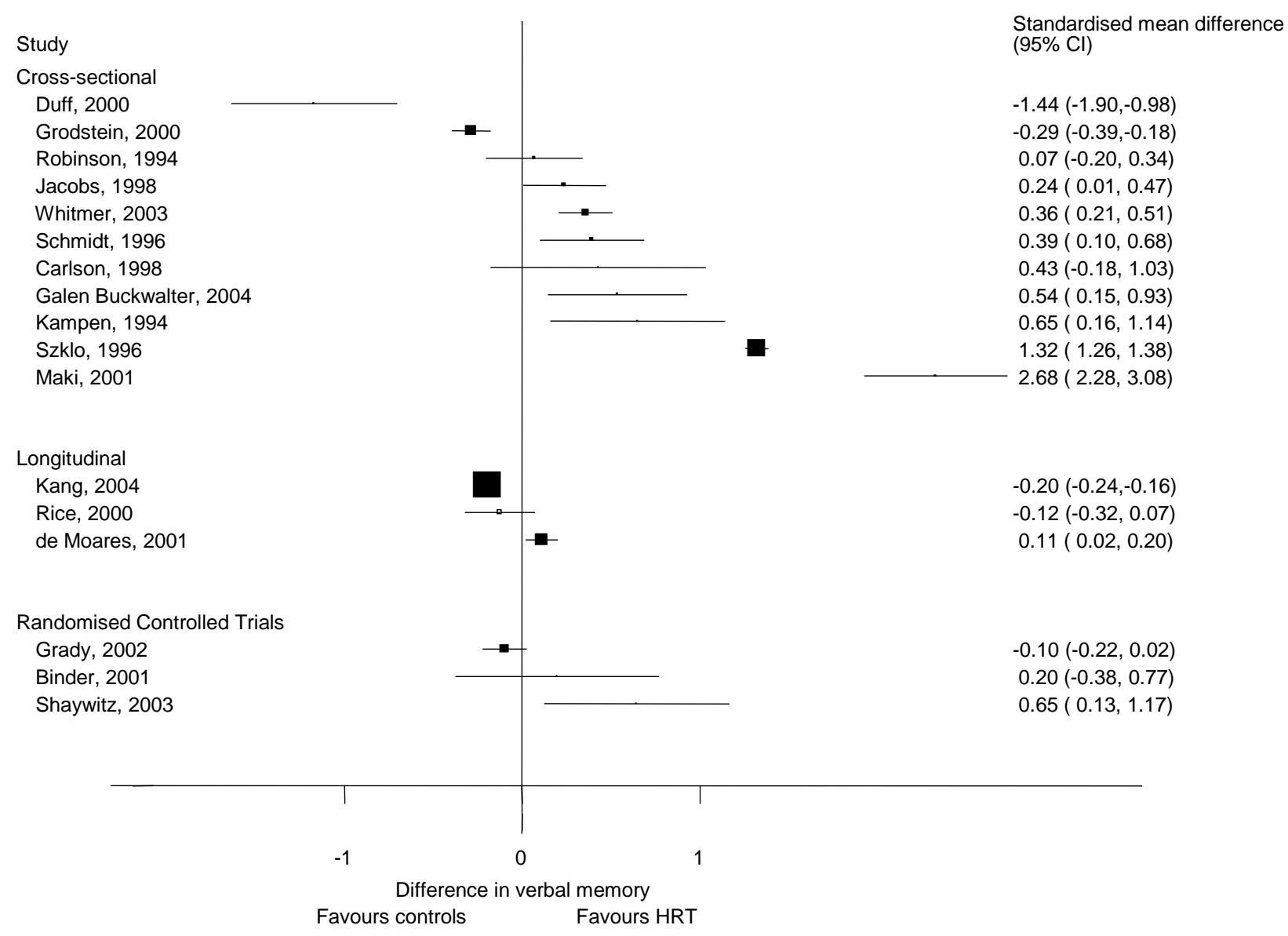

Fig. 1. The association between HRT and verbal memory performance.

$\mathrm{df}=2, p=0.000)$, though the two randomised-controlled trials were not significantly heterogeneous $\left(\chi^{2}=0.39\right.$, $\mathrm{df}=1, p=0.533$, respectively).

A meta-regression found no influence of age or duration of HRT use on the standardised mean difference between groups (coefficient $=-0.0514, p=0.213$, coefficient $=$ $0.0712, p=0.118$, respectively). Egger's test for funnel plot asymmetry was non-significant $(p=0.888)$.

The effect sizes from studies reporting data on the relationship between HRT and executive function and

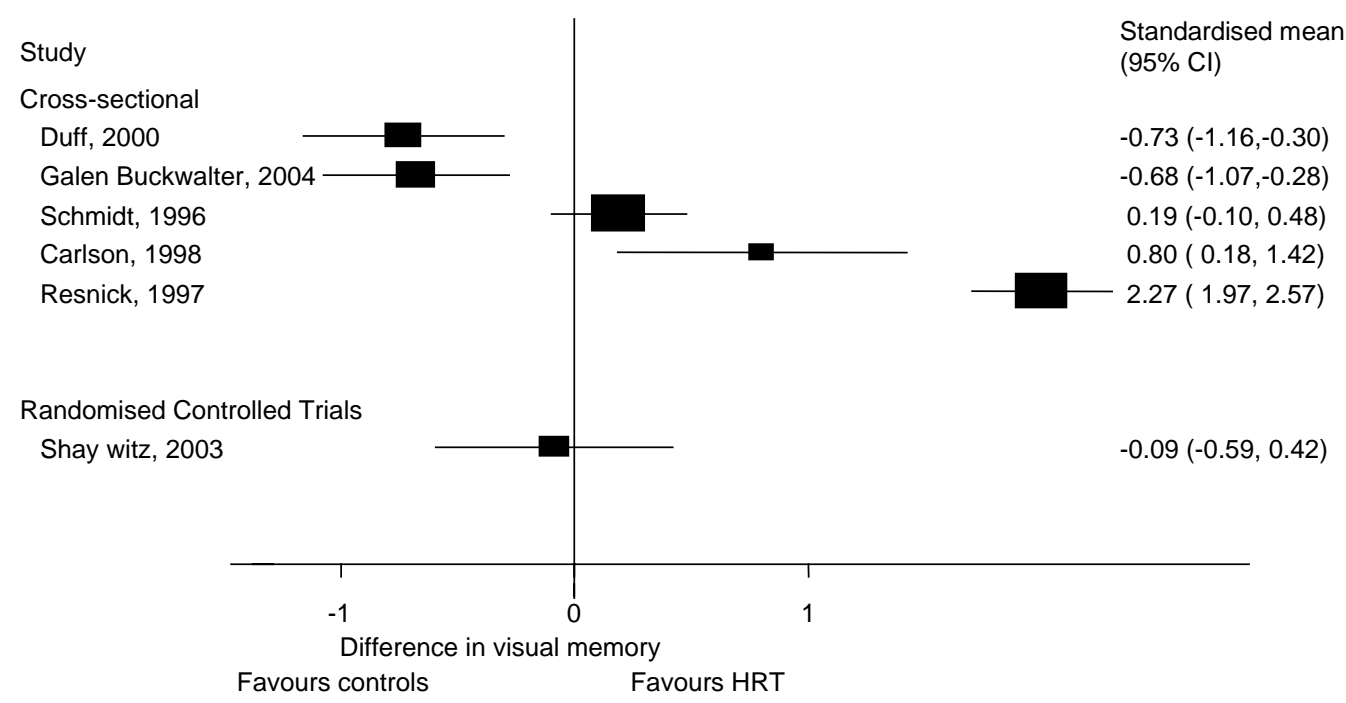

Fig. 2. The association between HRT and visual memory performance. 


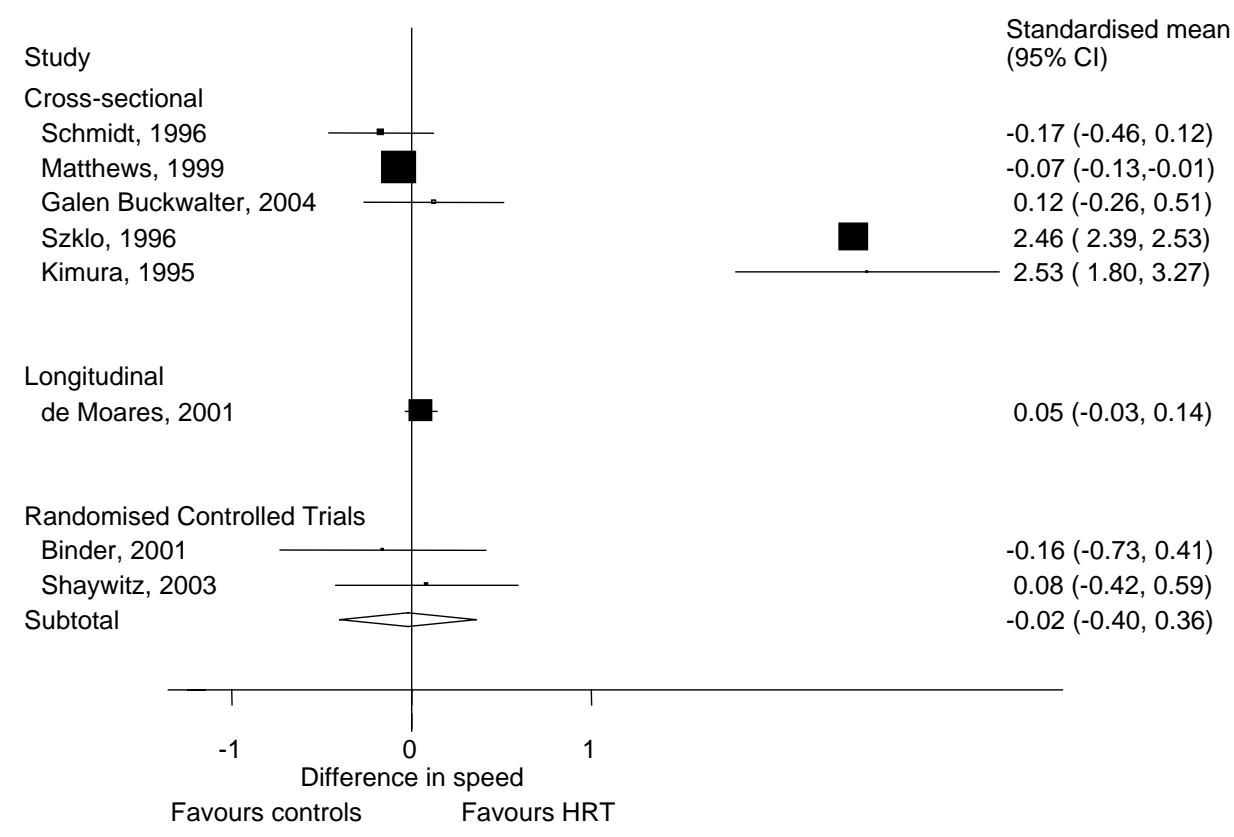

Fig. 3. The association between HRT and speed.

concept formation are presented in Fig. 4. Nine of the 10 cross-sectional studies reported a positive effect of HRT, and one reported no significant association. Of the three longitudinal studies, one reported a positive association, one a negative association and one no significant association. Two of the three randomised trials reported no association, and one reported a negative association. Most effect sizes were large for cross-sectional and longitudinal studies and small for randomised studies.

\subsection{1}

Cross-sectional studies reported a positive association between HRT and executive function that was not detected in longitudinal and randomised trials. This does not allow conclusions to be drawn on the relationship between HRT and executive function.

\subsection{HRT and cognitive screening test scores}

Sixteen papers measured the relationship between HRT and performance on cognitive screening instruments. There was insufficient information published in five of these papers to calculate effect sizes, two of these reported no significant relationship (Polo-Kantola et al., 1998; Robinson et al., 1994), and three reported a positive association (Barrett-Connor and Goodman-Gruen, 1999; Fillenbaum et al., 2001; Funk et al., 1991; Matthews et al., 1999). There was significant statistical heterogeneity between the five cross-sectional, four longitudinal and three randomised-controlled trials examined $\left(\chi^{2}=4582.80, \mathrm{df}=4, p=0.000 ; \chi^{2}=1837.46, \mathrm{df}=3, p=\right.$ $0.000 ; \chi^{2}=1430.69, \mathrm{df}=2, \quad p=0.000$, respectively).
A meta-regression revealed no significant influence of age or duration of HRT use on differences between groups effect size (coefficient $=0.117, p=0.586$, coefficient $=0.222, p=0.155$, respectively). On visual inspection, the funnel plot appeared asymmetrical, but Egger's test of funnel plot asymmetry was non-significant $(p=0.070)$.

Effect sizes from studies of the relationship between HRT and performance on cognitive screening instruments are presented in Fig. 5. There was a large range in results, with two cross-sectional studies reporting no relationship and three reporting a positive relationship (one with a very large effect size), one larger longitudinal study reporting no relationship and two reporting a positive relationship. Two randomisedcontrolled trials reported no relationship and one reported a negative relationship.

\subsection{1}

There is contradictory evidence between observational and randomised trials on the effects of HRT on performance on cognitive screening instruments. Overall it would appear that there is no positive effect and there may even be a small negative effect of HRT on cognitive screening instruments.

\subsection{HRT and risk of dementia}

Eighteen studies were identified that presented data on the risk of dementia associated with HRT use (Amaducci et al., 1986; Baldereschi et al., 1998; Barnes et al., 2003; Brenner et al., 1994; Broe et al., 1990; Graves et al., 1990; Henderson et al., 1994; Heyman et al., 1984; Kawas et al., 


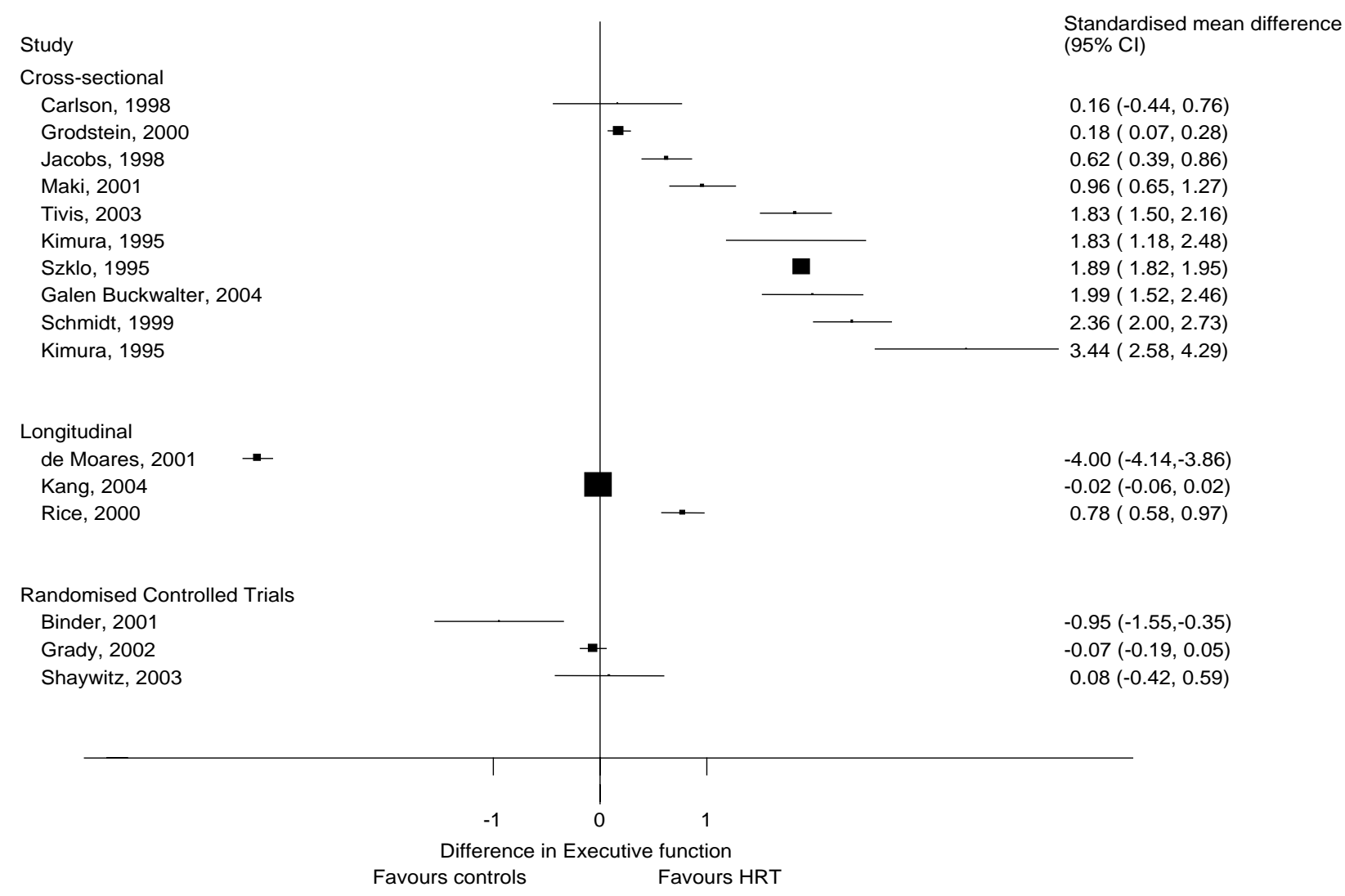

Fig. 4. The association between HRT and executive function and concept formation performance.

1997; Lindsay et al., 2002; Mortel and Meyer, 1995; Paganini-Hill and Henderson, 1996. Seshadri et al., 2001; Shumaker et al., 2004; Shumaker et al., 2003; Slooter et al., 1999; Tang et al., 1996; Waring et al., 1999; Zandi et al., 2002). Of these, 11 studies were cross-sectional, six were longitudinal and one was a randomised-controlled trial. There was significant statistical heterogeneity among cross-sectional, but not longitudinal studies $\left(\chi^{2}=17.72\right.$, $\mathrm{df}=10, \quad p=0.060 ; \quad \chi^{2}=15.00, \quad \mathrm{df}=5, \quad p=0.010$, respectively). Egger's test of asymmetry was non-significant $(p=0.400)$.

Risk ratios from the studies of HRT and dementia are presented in Fig. 6. Two cross-sectional, and four longitudinal studies reported significantly reduced risk of dementia with HRT use, nine cross-sectional and two longitudinal studies reported no significant difference in risk, and the single randomised-controlled trial found significantly increased risk.

\subsection{1}

The observational studies, particularly longitudinal studies, provided evidence that HRT reduced risk of dementia, but this was in contradiction to the results of the randomised-controlled trial that found increased risk of dementia.

\section{Discussion}

Contrary to hypotheses and evidence from laboratory and animal studies showing neurogenesis and neuroprotection, this review did not find consistent positive associations between HRT use and cognition in any cognitive domain. There may be negative effects of HRT on performance on cognitive screening instruments. Similar to the review by Zec and Trivedi (2002) we found that there were many non-significant results, although positive results tended to favour HRT users over controls. Notably, these data suggest an inverse relationship between study design and effect size, with most studies reporting positive relationships between HRT and cognition being cross-sectional. Longitudinal observational studies and randomised-controlled trials reported fewer positive relationships and several reported significant negative effects. Cross-sectional studies are most vulnerable to confounding through subject selection. Observational cross-sectional and longitudinal studies of dementia risk suggested that HRT is protective against dementia, but one randomised-controlled trial found increased risk. This pattern of results was similar to that found in cardiovascular disease where positive effects of HRT detected in observational studies were not substantiated in randomised-controlled trials (Yaffe, 2003). 
Study

Cross-sectional

Robinson, 1994

Grodstein, 2000

Whitmer, 2003

Luoto, 2000

Steffens, 1999

Longitudinal

Kang, 2004

Carlson, 2001

Yaffe, 2000

Rice, 2000

Randomised Controlled Trials

Espeland, 2004

Grady, 2002

Binder, 2001

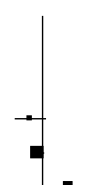

Standardised mean difference $(95 \% \mathrm{Cl})$

$-0.21(-0.48,0.06)$

$-0.08(-0.18,0.03)$

$0.46(0.32,0.61)$

$4.52(4.32,4.72)$

- $12.78(12.34,13.21)$

$-0.05(-0.09,-0.00)$

$0.23(0.14,0.32)$

$2.65(2.51,2.79)$

$3.73(3.44,4.01)$

$-2.63(-2.69,-2.56)$

$-0.05(-0.17,0.07)$

$-0.03(-0.60,0.54)$

\begin{tabular}{l|l|l|l|l|l|l}
\hline & & & & & & \\
-3 & -2 & -1 & 0 & 1 & & 10 \\
\multicolumn{2}{l}{$\begin{array}{l}\text { Difference in cognitive scores } \\
\text { Favours controls }\end{array}$} & 5 & 10
\end{tabular}

Favours controls

Favours HRT

Fig. 5. The association between HRT and cognitive screening test scores.

Study

Cross-sectional

Baldereschi, 1998

Henderson, 1994

Slooter, 1999

Waring, 1999

Mortel, 1995

Amaducci, 1986

Broe, 1990

Brenner, 1994

Graves, 1990

Seshadri, 2001

Heyman, 1984

Subtotal

Longitudinal

Zandi, 2002

Tang, 1996

Kawas, 1997

Lindsay, 2002

Paganini-Hill, 1996

Barnes, 2003

Randomised Controlled

Shumaker, 2004

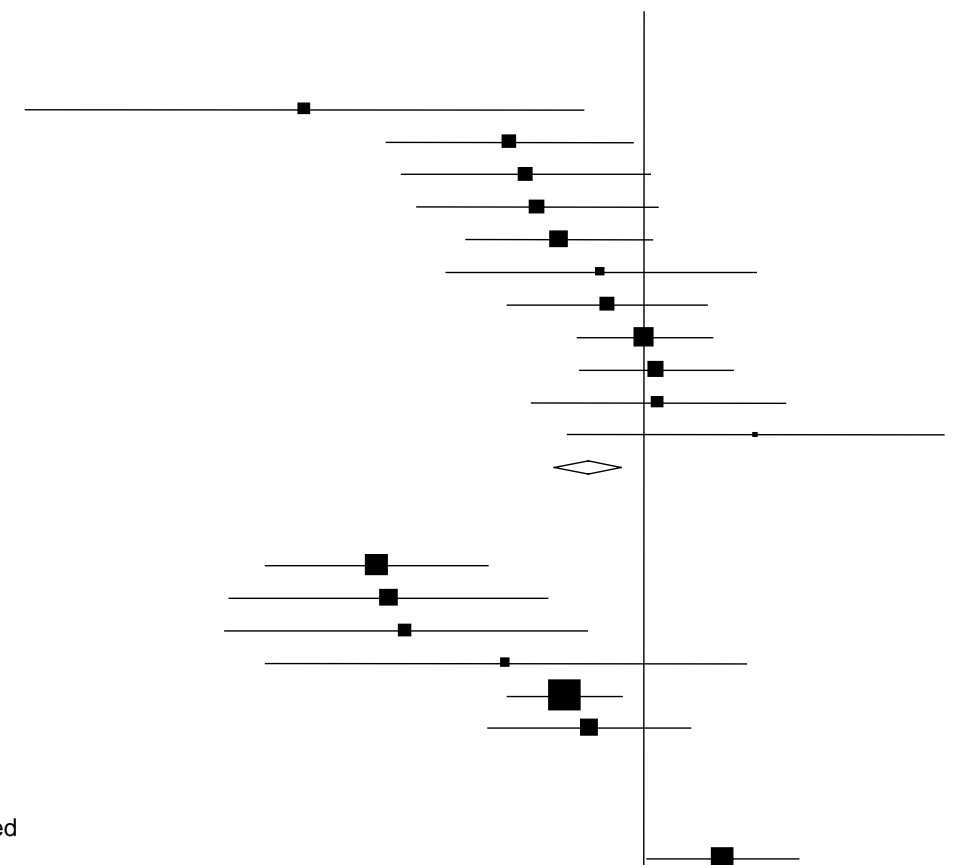

Risk ratio

(95\% Cl)

$0.25(0.08,0.78)$

$0.58(0.35,0.96)$

$0.62(0.37,1.03)$

$0.65(0.40,1.06)$

$0.71(0.48,1.04)$

$0.84(0.45,1.58)$

$0.86(0.57,1.30)$

$1.01(0.76,1.32)$

$1.06(0.77,1.44)$

$1.06(0.63,1.78)$

$1.58(0.73,3.41)$

$0.80(0.70,0.91)$

$0.34(0.21,0.53)$

$0.35(0.18,0.68)$

$0.38(0.18,0.79)$

$0.57(0.21,1.52)$

$0.73(0.57,0.92)$

$0.80(0.53,1.22)$

19.9

13.2

7.3

4.0

42.3

13.3

$1.38(1.02,1.88)$

100.0

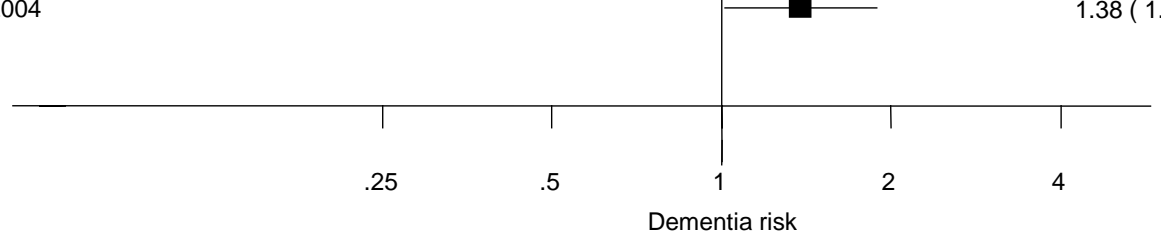

Favours HRT

Favours Controls

Fig. 6. The association between HRT and risk of dementia 
One interpretation of these results is that there are no true cognitive enhancing or protective effects of HRT and that positive results reported were due to other possibly preexisting differences between HRT users and non-users.

The data in this review could not address the question of whether the age at which HRT is commenced affects its impact on cognition. It may be that HRT only has a positive effect when commenced during the perimenopause or shortly after menopause (Sherwin, 2005). There have been suggestions that randomised-controlled trials of HRT here were commenced too long post menopause to have a positive effect on either cognition or cardiovascular disease (Naftolin et al., 2004; Studd, 2004). For instance in the Women's Health Initiative study, the mean age of subjects was 73, 22 years above the average age of menopause of 51 in the USA. If HRT provides neuroprotection sustaining levels of estrogen through HRT from menopause onwards may help prevent decline, but if commenced some time after menopause, neuronal health may already have deteriorated to a level where estrogen is no longer efficacious. This theory is supported by post hoc analysis from the Women's Health Initiative study that found that the risk of dementia for women who had never taken HRT was greater than for women who had previously used HRT, though this difference was non-significant (Shumaker et al., 2004). One observational study also found higher risk of cognitive decline in women who were older when they began HRT (Kang et al., 2004). Although in this review meta-regressions did not find that subjects' age at assessment or average duration of HRT influenced effect sizes, this could have been because all studies recruited postmenopausal women. If HRT is neuroprotective, then absolute age or duration of HRT may not be as important as whether estrogen levels are maintained through menopause and postmenopausally.

The theory that estrogen is neuroprotective was supported by the results of observational studies showing that HRT may decrease risk of dementia, and this decreased risk was observed both in current and ever users of HRT. However, the WHI randomised trial showed that HRT was associated with increased risk of dementia when commenced at age 60 years and older. This has led to suggestions that there is a critical period around menopause in which estrogen levels should be maintained in order to achieve this neuroprotection (Resnick and Henderson, 2002; Schneider, 2004; Sherwin, 2005).

The estrogen type most used by women in observational studies was oral conjugated equine estrogen. This was also the estrogen type tested in most randomised trials, with the most common dose at $0.625 \mathrm{mg} /$ day. Different hormone regimens result in different levels of bioavailable estrogen in the blood (Nachtigall et al., 2000), so other hormone regimens may prove more efficacious (Welty, 2003), though there is only limited evidence to support this. For instance, two trials excluded from this review because of small sample sizes administered injections of estradiol valerate at menopause and reported positive effects on cognition (Phillips and Sherwin, 1992; Sherwin, 1988). Two other small excluded trials studying transdermal estradiol in patients with Alzheimer's disease also reported positive effects on cognition (Asthana et al., 1999, 2001). Addition and type of progestin may also influence the effect of HRT, although there were no significant differences in cognitive outcomes between the estrogen and progestin and estrogen only arms of the Women's Health Initiative study (Shumaker et al., 2004).

Co-administration of other medications such as statins may impact on HRT. Statins alter the relationship between HRT and cardiovascular disease (Herrington et al., 2002; Hodis et al., 2001; Wakatsuki et al., 2002). But their interaction with HRT in regards to cognition is not known. Genetics may also change the impact of HRT on cognition. Some studies have found that HRT reduced the risk of cognitive impairment and improved episodic memory in women without the apolipoprotein 4 allele, but had no impact on women who were apolipoprotein 4 positive (Burkhardt et al., 2004; Yaffe et al., 2000). Race and other factors appear to affect the estradiol levels achieved during HRT, with one study finding non-Caucasian women, moderate drinkers and longer HRT users reached higher doses with oral HRT (Gavaler, 2002). Most studies were performed on samples where the majority of subjects were Caucasian; HRT may have larger effects on non-Caucasian women.

Ideally the relationship between HRT and cognitive function should be investigated further with several longterm randomised-controlled trials of women taking HRT from menopause, but given that the risks appear to outweigh the benefits from HRT (US Preventive Services Task Force, 2002), such trials would be considered unethical, and are unlikely in the future (MacLennan and Sturdee, 2002). Instead, observational studies should follow representative samples longitudinally from perimenopause to reduce possible confounding of other health and lifestyle variables. Both observational and experimental research should include neuropsychological tests in multiple cognitive domains, particularly verbal memory and executive functioning. Baseline confounding variables such as physical health, cardiovascular health, education and socio-economic levels should be controlled for as well as examining the interaction with other medications, such as statins. Negative results in this area should also be submitted for publication.

In conclusion, the evidence suggests that while there have been many studies reporting positive results, HRT use does not have a consistently positive effect on improving or maintaining cognition in any cognitive domain. Cognitive improvement or maintenance should not be listed as a secondary benefit of HRT. There was no evidence that HRT has a neuroenhancing effect resulting in overall improvement in cognition in humans. HRT may have a neuroprotective effect under certain circumstances, such as when HRT is 
taken from menopause onwards, or when taken by apolipoprotein 4 negative women, although exact circumstances, dose, administration route and duration of HRT use are not known. One possible reason no clear effect of HRT on cognition was detected is that HRT is neuroprotective rather than neuroenhancing. If this was the case, then in order for the effects of HRT to be detected, subjects have to be of sufficient age so that cognitive decline is observed in control subjects. Neuroimaging may reveal neuroprotective effects of HRT that are not yet detectable on cognitive testing.

\section{Acknowledgements}

We thank Emily Banks for her helpful comments on an earlier draft of this manuscript.

\section{References}

Adams, M.M., Fink, S.E., Shah, R.A., Janssen, W.G., Hayashi, S., Milner, T.A., McEwen, B.S., Morrison, J.H., 2002. Estrogen and aging affect the subcellular distribution of estrogen receptor-alpha in the hippocampus of female rats. Journal of Neuroscience 22, 3608-3614.

Amaducci, L.A., Fratiglioni, L., Rocca, W.A., Fieschi, C., Livrea, P., Pedone, D., Bracco, L., Lippi, A., Gandolfo, C., Bino, G., et al., 1986. Risk factors for clinically diagnosed Alzheimer's disease: a casecontrol study of an Italian population. Neurology 36, 922-931.

Angerer, P., Stork, S., Kothny, W., Schmitt, P., von Schacky, C., 2001 a. Effect of oral postmenopausal hormone replacement on progression of atherosclerosis: a randomized, controlled trial. Arteriosclerosis, Thrombosis and Vascular Biology 21, 262-268.

Angerer, P., Stork, S., von Schacky, C., 2001b. Influence of 17betaoestradiol on blood pressure of postmenopausal women at high vascular risk. Journal of Hypertension Supplement 19, 2135-2142.

Asthana, S., 2004. Estrogen and cognition: a true relationship? Journal of the American Geriatrics Society 52, 316-318.

Asthana, S., Craft, S., Baker, L.D., Raskind, M.A., Birnbaum, R.S., Lofgreen, C.P., Veith, R.C., Plymate, S.R., 1999. Cognitive and neuroendocrine response to transdermal estrogen in postmenopausal women with Alzheimer's disease: results of a placebo-controlled, double-blind, pilot study. Psychoneuroendocrinology 24, 657-677.

Asthana, S., Baker, L.D., Craft, S., Stanczyk, F.Z., Veith, R.C., Raskind, M.A., Plymate, S.R., 2001. High-dose estradiol improves cognition for women with AD: results of a randomized study. Neurology 57, 605612.

Bakken, K., Eggen, A.E., Lund, E., 1997. Hormone replacement therapy in Norwegian women, 1996-1997. Maturitas 40, 131-141.

Bakken, K., Eggen, A.E., Lund, E., 2001. Hormone replacement therapy in Norwegian women, 1996-1997. Maturitas 40, 131-141.

Baldereschi, M., Di Carlo, A., Lepore, V., Bracco, L., Maggi, S., Grigoletto, F., Scarlato, G., Amaducci, L., 1998. Estrogen-replacement therapy and Alzheimer's disease in the Italian longitudinal study on aging. Neurology 50, 996-1002.

Bardel, A., Wallander, M.A., Svardsudd, K., 2002. Hormone replacement therapy and symptom reporting in menopausal women: a populationbased study of 35-65-year-old women in mid-Sweden. Maturitas 41, $7-15$.

Barnes, L.L., Wilson, R.S., Schneider, J.A., Bienias, J.L., Evans, D.A., Bennett, D.A., 2003. Gender, cognitive decline, and risk of AD in older persons. Neurology 60, 1777-1781.
Barrett-Connor, E., Goodman-Gruen, D., 1999. Cognitive function and endogenous sex hormones in older women. Journal of the American Geriatrics Society 47, 1289-1293.

Barrett-Connor, E., Kritz-Silverstein, D., 1993. Estrogen replacement therapy and cognitive function in older women. Journal of American Medical Association 269, 2637-2641.

Binder, E.F., Schechtman, K.B., Birge, S.J., Williams, D.B., Kohrt, W.M., 2001. Effects of hormone replacement therapy on cognitive performance in elderly women. Maturitas 38, 137-146.

Brenner, D.E., Kukull, W.A., Stergachis, A., van Belle, G., Bowen, J.D., McCormick, W.C., Teri, L., Larson, E.B., 1994. Postmenopausal estrogen replacement therapy and the risk of Alzheimer's disease: a population-based case-control study. American Journal of Epidemiology 140, 262-267.

Breteler, M.M., Claus, J.J., Grobbee, D.E., Hofman, A., 1994. Cardiovascular disease and distribution of cognitive function in elderly people: the Rotterdam Study. British Medical Journal 308, 1604-1608.

Broe, G.A., Henderson, A.S., Creasey, H., McCusker, E., Korten, A.E., Jorm, A.F., Longley, W., Anthony, J.C., 1990. A case-control study of Alzheimer's disease in Australia. Neurology 40, 1698-1707.

Burkhardt, M.S., Foster, J.K., Laws, S.M., Baker, L.D., Craft, S., Gandy, S.E., Stuckey, B.G., Clarnette, R., Nolan, D., Hewson-Bower, B., Martins, R.N., et al., 2004. Oestrogen replacement therapy may improve memory functioning in the absence of APOE epsilon4. Journal of Alzheimer's Disease 6, 221-228.

Caldwell, B.M., 1954. An evaluation of psychological effects of sex hormone administration in aged women. Journal of Gerontology 9 , 168-174.

Campbell, S., Whitehead, M., 1977. Oestrogen therapy and the menopausal syndrome. Clinics in Obstetrics and Gynaecology 4, 31-47.

Carlson, L.E., Sherwin, B.B., 1998. Steroid hormones, memory and mood in a healthy elderly population. Psychoneuroendocrinology 23 , 583-603.

Carlson, M.C., Zandi, P.P., Plassman, B.L., Tschanz, J.T., Welsh-Bohmer, K.A., Steffens, D.C., Bastian, L.A., Mehta, K.M., Breitner, J.C., 2001. Cache County Study Group. 2001. Hormone replacement therapy and reduced cognitive decline in older women: the Cache County Study. Neurology 57, 2210-2216.

Clarke, S.C., Kelleher, J., Lloyd-Jones, H., Slack, M., Schofiel, P.M., 2002. A study of hormone replacement therapy in postmenopausal women with ischaemic heart disease: the Papworth HRT atherosclerosis study. BJOG: an International Journal of Obstetrics and Gynaecology 109, 1056-1062.

Clinical Synthesis Panel on HRT, 1999. Hormone replacement therapy. Lancet ( Hormone replacement therapy). 354, 152-155.

Cohen, J., 1988. Statistical Power for the Behavioral Sciences, second ed. Lawrence Erlbaum Associates, Hillsdale, New Jersey.

Coker, L.H., Shumaker, S.A., 2003. Type 2 diabetes mellitus and cognition: an understudied issue in women's health. Journal of Psychosomatic Research 54, 129-139.

Cook, I.A., Morgan, M.L., Dunkin, J.J., David, S., Witte, E., Lufkin, R., Abrams, M., Rosenberg, S., Leuchter, A.F., 2002. Estrogen replacement therapy is associated with less progression of subclinical structural brain disease in normal elderly women: a pilot study. International Journal of Geriatric Psychiatry 17, 610-618.

de la Torre, J.C., 2004. Is Alzheimer's disease a neurodegenerative or a vascular disorder?Data, dogma, and dialectics. Lancet Neurology 3, 184-190.

de Moraes, S.A., Szklo, M., Knopman, D., Park, E., 2001. Prospective assessment of estrogen replacement therapy and cognitive functioning: atherosclerosis risk in communities study. American Journal of Epidemiology 154, 733-739.

Deeks, J., Higgins, J., Riis, J., Silagy, C., 2002. In: Alderson, P., Green, S. (Eds.), Cochrane Collaboration open learning material for reviewers Version 1.1. Cochrane Collaboration. 
Ditkoff, E.C., Crary, W.G., Cristo, M., Lobo, R.A., 1991. Estrogen improves psychological function in asymptomatic postmenopausal women. Obstetrics and Gynecology 78, 991-995.

Duff, S.J., Hampson, E., 2000. A beneficial effect of estrogen on working memory in postmenopausal women taking hormone replacement therapy. Hormones and Behavior 38, 262-276.

Duka, T., Tasker, R., McGowan, J.F., 2000. The effects of 3-week estrogen hormone replacement on cognition in elderly healthy females. Psychopharmacology 149, 129-139.

Eberling, J.L., Wu, C., Haan, M.N., Mungas, D., Buonocore, M., Jagust, W.J., 2003. Preliminary evidence that estrogen protects against age-related hippocampal atrophy. Neurobiology of Aging 24, 725-732.

Egger, M., Smith, G.D., Schneider, M., Minder, C., 1997. Bias in metaanalysis detected by a simple, graphical test. British Medical Journal 315, 629-634.

Espeland, M.A., Marcovina, S.M., Miller, V., Wood, P.D., Wasilauskas, C., Sherwin, R., Schrott, H., Bush, T.L., et al., 1998. Effect of postmenopausal hormone therapy on lipoprotein(a) concentration, PEPI Investigators. Postmenopausal Estrogen/Progestin Interventions. Circulation 97, 979-986.

Espeland, M.A., Rapp, S.R., Shumaker, S.A., Brunner, R., Manson, J.E., Sherwin, B.B., Hsia, J., Margolis, K.L., Hogan, P.E., Wallace, R., Dailey, M., Freeman, R., Hays, J., 2004. Women's Health Initiative Memory Study, Conjugated equine estrogens and global cognitive function in postmenopausal women: Women's Health Initiative Memory Study. Journal of American Medical Association 291, 29592968.

Evio, S., Tiitinen, A., Turpeinen, U., Ylikorkala, O., 2000. Failure of the combination of sequential oral and transdermal estradiol plus norethisterone acetate to affect plasma homocysteine levels. Fertility and Sterility 74, 1080-1083.

Farag, N.H., Barshop, B.A., Mills, P.J., 2003. Effects of estrogen and psychological stress on plasma homocysteine levels. Fertility and Sterility 79, 256-260.

Fillenbaum, G.G., Hanlon, J.T., Landerman, L.R., Schmader, K.E., 2001. Impact of estrogen use on decline in cognitive function in a representative sample of older community-resident women. American Journal of Epidemiology 153, 137-144.

Fillit, H.M., 2002. The role of hormone replacement therapy in the prevention of Alzheimer disease. Archives of Internal Medicine 162, 1934-1942.

Finley, C., Gregg, E.W., Solomon, L.J., Gay, E., 2001. Disparities in hormone replacement therapy use by socioeconomic status in a primary care population. Journal of Community Health Nursing 26, $39-50$.

Funk, J.L., Mortel, K.F., Meyer, J.S., 1991. Effects of estrogen replacement therapy on cerebral perfusion and cognition among postmenopausal women. Dementia 2, 268-272.

Galen Buckwalter, J., Crooks, V.C., Robins, S.B., Petitti, D.B., 2004. Hormone use and cognitive performance in women of advanced age. Journal of the American Geriatrics Society 52, 182-186.

Galobardes, B., Costanza, M.C., Bernstein, M.S., Delhumeau, C.H., Morabia, A., 2003. Trends in risk factors for the major lifestyle-related diseases in Geneva, Switzerland, 1993-2000. Annals of Epidemiology $13,537-540$.

Gavaler, J.S., 2002. Oral hormone replacement therapy: factors that influence the estradiol concentrations achieved in a multiracial study population. Journal of Clinical Pharmacology 42, 137-144.

Genazzani, A.R., Gambacciani, M., 1999. Hormone replacement therapy: the perspectives for the 21st century. Maturitas 32, 11-17.

Gibbs, R.B., 1998. Impairment of basal forebrain cholinergic neurons associated with aging and long-term loss of ovarian function. Experimental Neurology 151, 289-302.

Goebel, J.A., Birge, S.J., Price, S.C., Hanson, J.M., Fishel, D.G., 1995. Estrogen replacement therapy and postural stability in the elderly. American Journal of Otolaryngology 16, 470-474.
Gorelick, P.B., Erkinjuntti, T., Hofman, A., Rocca, W.A., Skoog, I., Winblad, B., et al., 1999. Prevention of vascular dementia. Alzheimer Disease and Associated Disorders 13.

Grady, D., Yaffe, K., Kristof, M., Lin, F., Richards, C., Barrett-Connor, E., 2002. Effect of postmenopausal hormone therapy on cognitive function: the heart and estrogen/progestin replacement study. American Journal of Industrial Medicine 113, 543-548.

Graves, A.B., White, E., Koepsell, T.D., Reifler, B.V., van Belle, G., Larson, E.B., Raskind, M., 1990. A case-control study of Alzheimer's disease. Annals of Neurology 28, 766-774.

Grodstein, F., 1996. Invited commentary: can selection bias explain the cardiovascular benefits of estrogen replacement therapy? American Journal of Epidemiology 143, 979-982.

Grodstein, F., Chen, J., Pollen, D.A., Albert, M.S., Wilson, R.S., Folstein, M.F., Evans, D.A., Stampfer, M.J., 2000. Postmenopausal hormone therapy and cognitive function in healthy older women. Journal of the American Geriatrics Society 48, 746-752.

Hackman, B.W., Galbraith, D., 1976. Replacement therapy and piperazine oestrone sulphate ('Harmogen') and its effect on memory. Current Medical Research and Opinion 4, 303-306.

Hak, A.E., Bak, A.A., Lindemans, J., Planellas, J., Coelingh Bennink, H.J., Hofman, A., Grobbee, D.E., Witteman, J.C., 2001. The effect of hormone replacement therapy on serum homocysteine levels in perimenopausal women: a randomized controlled trial. Atherosclerosis 158, 437-443.

Henderson, V.W., Paganini-Hill, A., Emanuel, C.K., Dunn, M.E., Buckwalter, J.G., 1994. Estrogen replacement therapy in older women, Comparisons between Alzheimer's disease cases and nondemented control subjects. Archives of Neurology 51, 896-900.

Herrington, D.M., Reboussin, D.M., Brosnihan, K.B., Sharp, P.C., Shumaker, S.A., Snyder, T.E., Furberg, C.D., Kowalchuk, G.J., Stuckey, T.D., Rogers, W.J., Givens, D.H., Waters, D., 2000. Effects of estrogen replacement on the progression of coronaryartery atherosclerosis. The New England Journal of Medicine 343, 522-529.

Herrington, D.M., Vittinghoff, E., Lin, F., Fong, J., Harris, F., Hunninghake, D., Bittner, V., Schrott, H.G., Blumenthal, R.S., Levy, R., 2002. cardiovascular events, and total mortality in the Heart and Estrogen/Progestin Replacement Study (HERS). Circulation 105, 2962-2967.

Heyman, A., Wilkinson, W.E., Stafford, J.A., Helms, M.J., Sigmon, A.H., Weinberg, T., 1984. Alzheimer's disease: a study of epidemiological aspects. Annals of Neurology 15, 335-341.

Hodis, H.N., Mack, W.J., Lobo, R.A., Shoupe, D., Sevanian, A., Mahrer, P.R., Selzer, R.H., Liu Cr, C.R., Liu Ch, C.H., Azen, S.P., 2001. Estrogen in the Prevention of Atherosclerosis Trial Research Group. 2001. Estrogen in the prevention of atherosclerosis. A randomized, double-blind, placebo-controlled trial. Annals of Internal Medicine 135, 939-953.

Hogervorst, E., Boshuisen, M., Riedel, W., Willeken, C., Jolles, J., 1999. 1998 Curt P. Richter Award. The effect of hormone replacement therapy on cognitive function in elderly women. Psychoneuroendocrinology 24, 43-68.

Hogervorst, E., Yaffe, K., Richards, M., Huppert, F., 2004. Hormone Replacement therapy for Cognitive Function in Postmenopausal women (Cochrane Review). The Cochrane Library John Wiley and Sons Ltd, Chichester, UK.

Hulley, S., Grady, D., Bush, T., Furberg, C., Herrington, D., Riggs, B., Vittinghoff, E., 1998. Randomized trial of estrogen plus progestin for secondary prevention of coronary heart disease in postmenopausal women. Heart and Estrogen/progestin Replacement Study (HERS) Research Group. Journal of American Medical Association 280, 605-613.

Jacobs, D.M., Tang, M.X., Stern, Y., Sano, M., Marder, K., Bell, K.L., Schofield, P., Dooneief, G., Gurland, B., Mayeux, R., 1998. Cognitive function in nondemented older women who took estrogen after menopause. Neurology 50, 368-373. 
Janowsky, J.S., Chavez, B., Orwoll, E., 2000. Sex steroids modify working memory. Journal of Cognitive Neuroscience 12, 407-414.

Kampen, D.L., Sherwin, B.B., 1994. Estrogen use and verbal memory in healthy postmenopausal women. Obstetrics and Gynecology 83, 979-983.

Kanaya, A.M., Herrington, D., Vittinghoff, E., Lin, F., Grady, D., Bittner, V., Cauley, J.A., Barrett-Connor, E., 2003. Heart, Estrogen/progestin Replacement Study, I. 2003. Glycemic effects of postmenopausal hormone therapy: the Heart and estrogen/progestin replacement study. A randomized, double-blind, placebo-controlled trial. Annals of Internal Medicine 138, 1-9.

Kang, J.H., Weuve, J., Grodstein, F., 2004. Postmenopausal hormone therapy and risk of cognitive decline in community-dwelling aging women. Neurology 63, 101-107.

Kawas, C., Resnick, S., Morrison, A., Brookmeyer, R., Corrada, M., Zonderman, A., Bacal, C., Lingle, D.D., Metter, E., 1997. A prospective study of estrogen replacement therapy and the risk of developing Alzheimer's disease: the Baltimore longitudinal study of aging. Neurology 48, 1517-1521.

Keenan, P.A., Ezzat, W.H., Ginsburg, K., Moore, G.J., 2001. Prefrontal cortex as the site of estrogen's effect on cognition. Psychoneuroendocrinology 26, 577-590.

Kimura, D., 1995. Estrogen replacement therapy may protect against intellectual decline in postmenopausal women. Hormones and Behavior 29, 312-321.

Kompoliti, K., Chu, Y., Polish, A., Roberts, J., McKay, H., Mufson, E.J., Leurgans, S., Morrison, J.H., Kordower, J.H., 2004. Effects of estrogen replacement therapy on cholinergic basal forebrain neurons and cortical cholinergic innervation in young and aged ovariectomized rhesus monkeys. The Journal of Comparative Neurology 472, 193-207.

Kritzer, M.F., Kohama, S.G., 1999. Ovarian hormones differentially influence immunoreactivity for dopamine beta-hydroxylase, choline acetyltransferase, and serotonin in the dorsolateral prefrontal cortex of adult rhesus monkeys. The Journal of Comparative Neurology 409, $438-451$.

Kugaya, A., Epperson, C.N., Zoghbi, S., van Dyck, C.H., Hou, Y., Fujita, M., Staley, J.K., Garg, P.K., Seibyl, J.P., Innis, R.B., 2003. Increase in prefrontal cortex serotonin $2 \mathrm{~A}$ receptors following estrogen treatment in postmenopausal women. The American Journal of Psychiatry 160, $1522-1524$.

Lacreuse, A., Wilson, M.E., Herndon, J.G., 2002. Estradiol, but not raloxifene, improves aspects of spatial working memory in aged ovariectomized rhesus monkeys. Neurobiology of Aging 23, 589-600.

Lawrence, M., Jones, L., Lancaster, T., Daly, E., Banks, E., 1999. Hormone replacement therapy: patterns of use studied through British general practice computerized records. Family Practice 16, 335-342.

LeBlanc, E.S., Janowsky, J., Chan, B.K., Nelson, H.D., 2001. Hormone replacement therapy and cognition: systematic review and metaanalysis. Journal of American Medical Association 285, 1489-1499.

Lee, S.J., McEwen, B.S., 2001. Neurotrophic and neuroprotective actions of estrogens and their therapeutic implications. Annual Review of Pharmacology and Toxicology 41, 569-591.

Lezak, M.D., Mowieson, D.B., Loring, D.W., 2004. Neuropsychological Assessment, 4th ed. Oxford University Press, New York.

Lindsay, J., Laurin, D., Verreault, R., Hebert, R., Helliwell, B., Hill, G.B., McDowell, I., 2002. Risk factors for Alzheimer's disease: a prospective analysis from the Canadian study of health and aging. American Journal of Epidemiology 156, 445-453.

Lip, G.Y., Beevers, G., Zarifis, J., 1995. Hormone replacement therapy and cardiovascular risk: the cardiovascular physicians' viewpoint. Annals of Internal Medicine 238, 389-399.

Lithell, H., Hansson, L., Skoog, I., Elmfeldt, D., Hofman, A., Olofsson, B., Trenkwalder, P., Zanchetti, A., 2003. Scope Study Group. 2003. The study on cognition and prognosis in the elderly (SCOPE): principal results of a randomized double-blind intervention trial. Journal of Hypertension Supplement 21, 875-886.
Lokkegaard, E., Pedersen, A.T., Laursen, P., Loft, I.P., Larsen, S., Jorgensen, T., 2002. The influence of hormone replacement therapy on the aging-related change in cognitive performance. Analysis based on a Danish cohort study. Maturitas 42, 209-218.

Luoto, R., Manolio, T., Meilahn, E., Bhadelia, R., Furberg, C., Cooper, L., Kraut, M., 2000. Estrogen replacement therapy and MRI-demonstrated cerebral infarcts, white matter changes, and brain atrophy in older women: the Cardiovascular Health Study. Journal of the American Geriatrics Society 48, 467-472.

MacLennan, A., Sturdee, D., 2002. The end of WISDOM. Climacteric 5, 313-316.

MacLennan, A.H., Wilson, D.H., Taylor, A.W., 2002. Hormone replacement therapy use over a decade in an Australian population. Climacteric 5, 351-356.

Maki, P.M., Resnick, S.M., 2000. Longitudinal effects of estrogen replacement therapy on PET cerebral blood flow and cognition. Neurobiology of Aging 21, 373-383.

Maki, P., Zonderman, A., Resnick, S., 2001. Enhanced verbal memory in nondemented elderly women receiving hormone-replacement therapy. The American Journal of Psychiatry 158, 227-233.

Margolis, K.L., Bonds, D.E., Rodabough, R.J., Tinker, L., Phillips, L.S., Allen, C., Bassford, T., Burke, G., Torrens, J., Howard, B.V., 2004. Women's Health Initiative, I. 2004. Effect of oestrogen plus progestin on the incidence of diabetes in postmenopausal women: results from the Women's Health Initiative Hormone Trial. Diabetologia 47, 1175-1187.

Matthews, K.A., Kuller, L.H., Wing, R.R., Meilahn, E.N., Plantinga, P., 1996. Prior to use of estrogen replacement therapy, are users healthier than nonusers? American Journal of Epidemiology 143, 971-978.

Matthews, K., Cauley, J., Yaffe, K., Zmuda, J.M., 1999. Estrogen replacement therapy and cognitive decline in older community women. Journal of the American Geriatrics Society 47, 518-523.

McMichael, A.J., McKee, M., Shkolnikov, V., Valkonen, T., 2004. Mortality trends and setbacks: global convergence or divergence? Lancet 363, 1155-1159.

Mijatovic, V., Netelenbos, C., van der Mooren, M.J., de Valk-de Roo, G.W., Jakobs, C., Kenemans, P., 1998. Randomized, double-blind, placebo-controlled study of the effects of raloxifene and conjugated equine estrogen on plasma homocysteine levels in healthy postmenopausal women. Fertility and Sterility 70, 1085-1089.

Miller, K.J., Conney, J.C., Rasgon, N.L., Fairbanks, L.A., Small, G.W., 2002. Mood symptoms and cognitive performance in women estrogen users and nonusers and men. Journal of the American Geriatrics Society 50, 1826-1830.

Mortel, K.F., Meyer, J.S., 1995. Lack of postmenopausal estrogen replacement therapy and the risk of dementia. Journal of Neuropsychiatry and Clinical Neurosciences 7, 334-337.

Murphy, D.D., Segal, M., 2000. Progesterone prevents estradiol-induced dendritic spine formation in cultured hippocampal neurons. Neuroendocrinology 72, 133-143.

Murphy, D.D., Cole, N.B., Segal, M., 1998. Brain-derived neurotrophic factor mediates estradiol-induced dendritic spine formation in hippocampal neurons. Proceedings of the National Academy of Sciences of the USA 95, 11412-11417.

Nachtigall, L.E., Raju, U., Banerjee, S., Wan, L., Levitz, M., 2000. Serum estradiol-binding profiles in postmenopausal women undergoing three common estrogen replacement therapies: associations with sex hormone-binding globulin, estradiol, and estrone levels. Menopause 7, 243-250.

Naftolin, F., Taylor, H.S., Karas, R., Brinton, E., Newman, I., Clarkson, T.B., Mendelsohn, M., Lobo, R.A., Judelson, D.R., Nachtigall, L.E., Heward, C.B., Hecht, H., Jaff, M.R., Harman, S.M., 2004. The Women's Health Initiative could not have detected cardioprotective effects of starting hormone therapy during the menopausal transition. Fertility and Sterility 81, 1498-1501. 
National Health and Medical Research Council, 2001.Anon., 2001. Guidelines for the Development and Implementation of Clinical Guidelines, first ed. Australian Government Publishing Service, Canberra.

North, F.M., Sharples, K., 2001. Changes in the use of hormone replacement therapy in New Zealand from 1991-1997. New Zealand Medical Journal 114, 250-253.

Ormerod, B.K., Galea, L.A., 2001. Reproductive status influences cell proliferation and cell survival in the dentate gyrus of adult female meadow voles: a possible regulatory role for estradiol. Neuroscience 102, 369-379.

Os, I., Os, A., Sandset, P.M., Bolling, S., Seljeflot, I., Djurovic, S., Westheim, A., 2002. Hormone replacement therapy does not affect plasma homocysteine in postmenopausal women with coronary artery disease. Free tissue factor pathway inhibitor antigen, a circulating anticoagulant, is related to plasma homocysteine. Cardiology 98, 6-12.

Paganini-Hill, A., Henderson, V.W., 1996a. The effects of hormone replacement therapy, lipoprotein cholesterol levels, and other factors on a clock drawing task in older women. Journal of the American Geriatrics Society 44, 818-822.

Paganini-Hill, A., Henderson, V.W., 1996b. Estrogen replacement therapy and risk of Alzheimer disease. Archives of Internal Medicine 156, 2213-2217.

Petitti, D.B., 2001. Approaches to heterogeneity in meta-analysis. Statistics in Medicine 20, 3625-3633.

Phillips, S.M., Sherwin, B.B., 1992. Effects of estrogen on memory function in surgically menopausal women. Psychoneuroendocrinology 17, 485-495.

Polo-Kantola, P., Portin, R., Polo, O., Helenius, H., Irjala, K., Erkkola, R., 1998. The effect of short-term estrogen replacement therapy on cognition: a randomized, double-blind, cross-over trial in postmenopausal women. Obstetrics and Gynecology 91, 459-466.

Poole, C., Greenland, S., 1999. Random-effects meta-analyses are not always conservative. American Journal of Epidemiology 150, 469-475.

Rapp, P.R., Morrison, J.H., Roberts, J.A., 2003a. Cyclic estrogen replacement improves cognitive function in aged ovariectomized rhesus monkeys. The Journal of Neuroscience Nursing 23, 5708-5714.

Rapp, S.R., Espeland, M.A., Shumaker, S.A., Henderson, V.W., Brunner, R.L., Manson, J.E., Gass, M.L., Stefanick, M.L., Lane, D.S., Hays, J., Johnson, K.C., Coker, L.H., Dailey, M., Bowen, D., 2003b. Effect of estrogen plus progestin on global cognitive function in postmenopausal women: the Women's Health Initiative Memory Study: a randomized controlled trial. Journal of American Medical Association 289, 2663 2672.

Rauramo, L., Lagerspetz, K., Engblom, P., Punnonen, R., 1975. The effect of castration and peroral estrogen therapy on some psychological functions. Frontiers of Hormone Research 3, 94-104.

Resnick, S.M., Henderson, V.W., 2002. Hormone therapy and risk of Alzheimer disease: A critical time. Journal of American Medical Association 288, 2170.

Resnick, S.M., Metter, E.J., Zonderman, A.B., 1997. Estrogen replacement therapy and longitudinal decline in visual memory. A possible protective effect? Neurology 49, 1491-1497.

Resnick, S.M., Maki, P.M., Golski, S., Kraut, M.A., Zonderman, A.B., 1998. Effects of estrogen replacement therapy on PET cerebral blood flow and neuropsychological performance. Hormones and Behavior 34 , 171-182.

Rice, M.M., Graves, A.B., McCurry, S.M., Gibbons, L.E., Bowen, J.D., McCormick, W.C., Larson, E.B., 2000. Postmenopausal estrogen and estrogen-progestin use and 2-year rate of cognitive change in a cohort of older Japanese American women: The Kame Project. Archives of Internal Medicine 160, 1641-1649.

Robertson, D.M., van Amelsvoort, T., Daly, E., Simmons, A., Whitehead, M., Morris, R.G., Murphy, K.C., Murphy, D.G., 2001. Effects of estrogen replacement therapy on human brain aging: an in vivo ${ }^{1} \mathrm{H}$ MRS study. Neurology 57, 2114-2117.
Robinson, D., Friedman, L., Marcus, R., Tinklenberg, J., Yesavage, J., 1994. Estrogen replacement therapy and memory in older women. Journal of the American Geriatrics Society 42, 919-922.

Rossi, R., Origliani, G., Modena, M.G., 2004. Transdermal 17-beta-estradiol and risk of developing type 2 diabetes in a population of healthy, nonobese postmenopausal women. Diabetes Care 27, 645-649.

Schmidt, R., Fazekas, F., Reinhart, B., Kapeller, P., Fazekas, G., Offenbacher, H., Eber, B., Schumacher, M., Freidl, W., 1996. Estrogen replacement therapy in older women: a neuropsychological and brain MRI study. Journal of the American Geriatrics Society 44, 1307-1313.

Schneider, L.S., 2004. Estrogen and Dememtia: Insights from the Women's Health Initiative Memory Study. Journal of American Medical Association 291, 3005.

Schulman, S.P., Thiemann, D.R., Ouyang, P., Chandra, N.C., Schulman, D.S., Reis, S.E., Terrin, M., Forman, S., de Albuquerque, C.p., Bahr, R.D., Townsend, S.N., Cosgriff, R., Gerstenblith, G., 2002. Effects of acute hormone therapy on recurrent ischemia in postmenopausal women with unstable angina. Journal of the American College of Cardiology 39, 231-237.

Seshadri, S., Zornberg, G.L., Derby, L.E., Myers, M.W., Jick, H., Drachman, D.A., 2001. Postmenopausal estrogen replacement therapy and the risk of Alzheimer disease. Archives of Neurology $58,435-440$.

Shaywitz, S.E., Naftolin, F., Zelterman, D., Marchione, K.E., Holahan, J.M., Palter, S.F., Shaywitz, B.A., 2003. Better oral reading and shortterm memory in midlife, postmenopausal women taking estrogen. Menopause 10, 420-426.

Sherwin, B.B., 1988. Estrogen and/or androgen replacement therapy and cognitive functioning in surgically menopausal women. Psychoneuroendocrinology 13, 345-357.

Sherwin, B.B., 2005. Estrogen and memory in women: how can we reconcile the findings? Hormones and Behavior 47, 371-375.

Shlipak, M.G., Chaput, L.A., Vittinghoff, E., Lin, F., Bittner, V., Knopp, R.H., Hulley, S.B., 2003. Heart Estrogen/progestin Replacement Study Investigators. 2003. Lipid changes on hormone therapy and coronary heart disease events in the Heart and Estrogen/progestin Replacement Study (HERS). American Heart Journal 146, 870-875.

Shumaker, S.A., Legault, C., Rapp, S.R., Thal, L., Wallace, R.B., Ockene, J.K., Hendrix, S.L., Jones 3rd., B.N., Assaf, A.R., Jackson, R.D., Kotchen, J.M., Wassertheil-Smoller, S., Wactawski-Wende, J., 2003. WHIMS Investigators. 2003. Estrogen plus progestin and the incidence of dementia and mild cognitive impairment in postmenopausal women: the Women's Health Initiative Memory Study: a randomized controlled trial. Journal of American Medical Association 289, 2651-2662.

Shumaker, S.A., Legault, C., Kuller, L., Rapp, S.R., Thal, L., Lane, D.S., Fillit, H., Stefanick, M.L., Hendrix, S.L., Lewis, C.E., Masaki, K., Coker, L.H., 2004. For the women's health initiative memory study. 2004. Conjugated equine estrogens and incidence of probable dementia and mild cognitive impairment in postmenopausal women: women's health initiative memory study. Journal of American Medical Association 291, 2947-2958.

Singh, M., Meyer, E.M., Millard, W.J., Simpkins, J.W., 1994. Ovarian steroid deprivation results in a reversible learning impairment and compromised cholinergic function in female Sprague-Dawley rats. Brain Research 644, 305-312.

Singh, M., Meyer, E.M., Simpkins, J.W., 1995. The effect of ovariectomy and estradiol replacement on brain-derived neurotrophic factor messenger ribonucleic acid expression in cortical and hippocampal brain regions of female Sprague-Dawley rats. Endocrinology 136, 2320-2324.

Slooter, A.J., Bronzova, J., Witteman, J.C., Van Broeckhoven, C., Hofman, A., van Duijn, C.M., 1999. Estrogen use and early onset Alzheimer's disease: a population-based study. Journal of Neurology, Neurosurgery and Psychiatry 67, 779-781.

Steffens, D.C., Norton, M.C., Plassman, B.L., Tschanz, J.T., Wyse, B.W., Welsh-Bohmer, K.A., Anthony, J.C., Breitner, J.C., 1999. Enhanced 
cognitive performance with estrogen use in nondemented communitydwelling older women. Journal of the American Geriatrics Society 47, 1171-1175.

Stephens, C., Ross, N., 2002. The relationship between hormone replacement therapy use and psychological symptoms: no effects found in a New Zealand sample. Health Care Women International 23, $408-414$.

Studd, J., 2004. Second thoughts on the women's health initiative study: the effect of age on the safety of HRT. Climacteric 7, 412-414.

Szklo, M., Cerhan, J., Diez-Roux, A.V., Chambless, L., Cooper, L., Folsom, A.R., Fried, L.P., Knopman, D., Nieto, F.J., 1996. Estrogen replacement therapy and cognitive functioning in the Atherosclerosis Risk in Communities (ARIC) Study. American Journal of Epidemiology 144, 1048-1057.

Tanapat, P., Hastings, N.B., Reeves, A.J., Gould, E., 1999. Estrogen stimulates a transient increase in the number of new neurons in the dentate gyrus of the adult female rat. The Journal of Neuroscience Nursing 19, 5792-5801.

Tang, M.X., Jacobs, D., Stern, Y., Marder, K., Schofield, P., Gurland, B., Andrews, H., Mayeux, R., 1996. Effect of oestrogen during menopause on risk and age at onset of Alzheimer's disease. Lancet 348, 429-432.

Tang, Y., Janssen, W.G., Hao, J., Roberts, J.A., McKay, H., Lasley, B., Allen, P.B., Greengard, P., Rapp, P.R., Kordower, J.H., Hof, P.R., Morrison, J.H., 2004. Estrogen replacement increases spinophilinimmunoreactive spine number in the prefrontal cortex of female rhesus monkeys. Cerebral Cortex 14, 215-223.

Teunissen, C.E., Blom, A.H., Van Boxtel, M.P., Bosma, H., de Bruijn, C., Jolles, J., Wauters, B.A., Steinbusch, H.W., de Vente, J., 2003. Homocysteine: a marker for cognitive performance? A longitudinal follow-up study. Journal of Nutrition, Health and Aging 7, 153-159.

The Women's Health Initiative Steering Committee, 2004. The Women's Health Initiative Steering Committee. Journal of American Medical Association 291, 1701-1712.

The Writing Group for the PEPI Trial, 1995. JAMA/Journal of American Medical Association1995, 199-208.

Thompson, S.G., 1994. Systematic review: why sources of heterogeneity in meta-analysis should be investigated. British Medical Journal 309, 1351-1355.

Thompson, S.G., Higgins, J.P., 2002. How should meta-regression analyses be undertaken and interpreted? Statistics in Medicine 21, 1559-1573.

Tivis, L.J., Green, M.D., Nixon, S.J., Tivis, R.D., 2003. Alcohol, estrogen replacement therapy, and visuospatial processes in postmenopausal women. Alcoholism: Clinical and Experimental Research 27, 1055-1063.

U. S. Preventive Services Task Force, 2002. Postmenopausal hormone replacement therapy for primary prevention of chronic conditions: recommendations and rationale. Annals of Internal Medicine 137, 834-839.

van Baal, W.M., Smolders, R.G., van der Mooren, M.J., Teerlink, T., Kenemans, P., 1999. Hormone replacement therapy and plasma homocysteine levels. Obstetrics and Gynecology 94, 485-491.

Vanhulle, G., Demol, P., 1976. In: Keep, P.A., Greenblatt, R.B., AlbeauxFernet, M. (Eds.), A Double-blind Study into the Influence of Estriol on a Number of Psychological Tests in Post-menopausal Women. Consensus on the menopause research MTP press, London, pp. 94-99.

Ventura, P., Cagnacci, A., Malmusi, S., Panini, R., Baldassari, F., Arangino, S., Volpe, A., Salvioli, G., 2001. Continuous combined hormone replacement therapy with oral 17 beta-estradiol and norethisterone acetate improves homocysteine metabolism in postmenopausal women. Menopause 8, 252-258.

Verghese, J., Kuslansky, G., Katz, M.J., Sliwinski, M., Crystal, H.A., Buschke, H., Lipton, R.B., 2000. Cognitive performance in surgically menopausal women on estrogen. Neurology 55, 872-874.
Verhaegen, P., Borchelt, M., Smith, J., 2003. Relation between cardiovascular and metabolic disease and cognition in very old age: cross-sectional and longitudinal findings from the Berlin Aging Study. Health Psychology 22, 559-569.

Viscoli, C.M., Brass, L.M., Kernan, W.N., Sarrel, P.M., Suissa, S., Horwitz, R.I., 2001. A clinical trial of estrogen-replacement therapy after ischemic stroke. The New England Journal of Medicine 345, $1243-1249$.

Wakatsuki, A., Okatani, Y., Fukaya, T., 2002. Statin attenuates increase in C-reactive protein during estrogen replacement therapy in postmenopausal women. Circulation 106, 198-199.

Walsh, B.W., Paul, S., Wild, R.A., Dean, R.A., Tracy, R.P., Cox, D.A., Anderson, P.W., 2000. The effects of hormone replacement therapy and raloxifene on C-reactive protein and homocysteine in healthy postmenopausal women: a randomized, controlled trial. Journal of Clinical Endocrinology and Metabolism 85, 214-218.

Waring, S.C., Rocca, W.A., Petersen, R.C., O’Brien, P.C., Tangalos, E.G., Kokmen, E., 1999. Postmenopausal estrogen replacement therapy and risk of AD: a population-based study. Neurology 52, 965-970.

Waters, D.D., Alderman, E.L., Hsia, J., Howard, B.V., Cobb, F.R., Rogers, W.J., Ouyang, P., Thompson, P., Tardif, J.C., Higginson, L., Bittner, V., Steffes, M., Gordon, D.J., Proschan, M., Younes, N., Verter, J.I., 2002. Effects of hormone replacement therapy and antioxidant vitamin supplements on coronary atherosclerosis in postmenopausal women: a randomized controlled trial. Journal of American Medical Association 288, 2432-2440.

Welty, F.K., 2003. Alternative hormone replacement regimens: is there a need for further clinical trials? Current Opinion in Lipidology 14, 585-591.

Whitmer, R.A., Haan, M.N., Miller, J.W., Yaffe, K., 2003. Hormone replacement therapy and cognitive performance: the role of homocysteine. Journals of Gerontology Series A-Biological Sciences and Medical Sciences 58, 324-330.

Wise, P.M., 2003a. Estrogens: protective or risk factors in brain function? Progress in Neuro-Psychopharmacology and Biological Psychiatry 69, 181-191.

Wise, P.M., 2003b. Impact of menopause on the brain. Alzheimer Disease and Associated Disorders 17, S48-S50.

Wolf, D.S., Gearing, M., Snowdon, D.A., Mori, H., Markesbery, W.R., Mirra, S.S., 1999. Progression of regional neuropathology in Alzheimer disease and normal elderly: findings from the Nun study. Alzheimer Disease and Associated Disorders 13, 226-231.

Writing Group for the Women's Health Initiative InvestigatorsAnderson, G.L., Prentice, R.L., LaCroix, A.Z., Kooperberg, C., Stefanick, M.L., Jackson, R.D., Beresford, S.A., Howard, B.V., Johnson, K.C., Kotchen, J.M., Ockene, J., 2002. Risks and benefits of estrogen plus progestin in healthy postmenopausal women: principal results From the Women's Health Initiative randomized controlled trial. Journal of American Medical Association 288, 321-333.

Yaffe, K., 2003. Hormone therapy and the brain: deja vu all over again? Journal of American Medical Association 289, 2717-2719.

Yaffe, K., Haan, M., Byers, A., Tangen, C., Kuller, L., 2000. Estrogen use, APOE, and cognitive decline: evidence of gene-environment interaction. Neurology 54, 1949-1954.

Yaffe, K., Barrett-Connor, E., Lin, F., Grady, D., 2002. Serum lipoprotein levels, statin use, and cognitive function in older women. Archives of Neurology 59, 378-384.

Zandi, P.P., Carlson, M.C., Plassman, B.L., Welsh-Bohmer, K.A., et al., 2002. Hormone replacement therapy and incidence of Alzheimer disease in older women: The Cache County Study. Journal of American Medical Association 288, 2123.

Zec, R.F., Trivedi, M.A., 2002. The effects of estrogen replacement therapy on neuropsychological functioning in postmenopausal women with and without dementia: a critical and theoretical review. Neuropsychology Review 12, 65-109. 